\title{
WHAT REPLACEMENT RATES DO HOUSEHOLDS ACTUALLY EXPERIENCE IN RETIREMENT?
}

\author{
Alicia H. Munnell and Mauricio Soto* \\ CRR WP 2005-10 \\ Released: August 2005 \\ Draft Submitted: August 2005
}
Center for Retirement Research at Boston College
550 Fulton Hall
140 Commonwealth Ave.
Chestnut Hill, MA 02467
Tel: 617-552-1762 Fax: 617-552-0191
http://www.bc.edu/crr

\begin{abstract}
* Alicia H. Munnell is the Director of the Center for Retirement Research (CRR) and the Peter F. Drucker Professor of Management Sciences at Boston College's Carroll School of Management. Mauricio Soto is an Economics graduate student at Boston College and a research associate at the Center. The research reported herein was performed pursuant to a grant from the U.S. Social Security Administration (SSA) to the Center for Retirement Research at Boston College (CRR). The findings and conclusions are solely those of the authors and do not represent the views of SSA, any agency of the Federal Government, or Boston College.
\end{abstract}

(C) 2005, by Alicia Munnell and Mauricio Soto. All rights reserved. Short sections of text, not to exceed two paragraphs, may be quoted without explicit permission provided that full credit, including $\odot$ notice, is given to the source. 


\begin{abstract}
This paper estimates how much people actually receive in retirement relative to earnings before retirement when all sources of income, including income generated by homeownership, are combined. Previous studies find that middle class people need between 70 and 75 percent of their pre-retirement earnings to maintain their life style once they stop working. The objective of this study is to determine what people are actually receiving in retirement.
\end{abstract}

Regardless of how retirement income and pre-retirement income are defined, households with pensions appear to meet the threshold of adequacy. Those without pensions do not fare as well, and some must be really struggling. Taking into account a comprehensive measure of income both before and after retirement — including housing — produces replacement rates for those with pensions of 79 percent for couples and 89 percent for single person households. Those without pensions have replacement rates of 62 percent for couples and 63 percent for singles. These replacement rates drop about 15 percentage points, however, when recent earnings (the highest five years of the last ten) are used as the benchmark. The overall the picture is good.

But today is in some sense the "golden age" of retirement income. Today's retirees are claiming Social Security benefits before the extension in the retirement age to 66 and then 67, which is equivalent to an across-the-board cut in benefits. Today's retirees also do not face the huge deductions in their Social Security check to cover Medicare premiums for Part $\mathrm{B}$ and Part D that tomorrow's retirees will. And today, the average retiree does not pay personal income tax on his Social Security benefits, whereas future retirees will increasingly see a portion of their benefits subject to taxation. Finally, most of today's retirees are covered primarily by a defined benefit plan and do not face the uncertainty associated with the inadequate lump-sum payments from 401(k) plans. The comfortable circumstances of today's retirees make it very hard to call attention to the challenges that future retirees will face. 
The replacement rate is a basic measure of the performance of retirement income systems. It gauges the extent to which benefits replace earnings before retirement and thereby allow workers to maintain a reasonable approximation of their pre-retirement standard of living. In the U.S. retirement income system, Social Security provides a basic level of replacement, upon which individuals can build through additional saving. This additional saving comes mainly through employer-sponsored pension plans and the accumulation of home equity. Most people save very little on their own outside of pensions and their home. This paper estimates how much people actually receive in retirement relative to earnings before retirement when all sources of income, including income generated by homeownership, are combined.

This task should be easy and straightforward. After all, Social Security publishes replacement rates for representative individuals -42 percent of pre-retirement earnings for the "medium earner;" 57 percent for the low earner; and 35 percent for the high earner. Simply add defined benefit pension replacement rates and annuitize some 401(k) accumulations and housing wealth, and call it a day. In fact, calculating replacement rates is complicated and messy. People do not have steady earnings histories, and many experience sharp declines in earnings in their 50s. So, it is not clear what earnings are to be replacedthat is, what should be in the denominator. Moreover, the adequacy of replacement rates appears to depend crucially on the treatment of housing, and the appropriate treatment of housing is complicated. So, it is also not clear what belongs in the numerator.

In an attempt to sort out these issues, this paper first discusses how much income people need in retirement and raises some conceptual issues involved in constructing replacement rates. The second section describes how Social Security derives its policy model replacement rates, evaluates existing evidence to assess the reasonableness of these hypothetical outcomes, and then compares individual earned replacement rates from the Health and Retirement Study to official Social Security numbers for new retirees. The third section moves from individual to household replacement rates and broadens the income sources to include employer-sponsored pensions and non-pension financial assets. The fourth section addresses the appropriate treatment of housing. The fifth section is the conclusion. 
Several very practical conclusions emerge from this analysis. First, for the population as a whole, median average indexed lifetime earnings are somewhat lower than that of Social Security's "medium earner," suggesting a somewhat higher replacement rate than the policy model. On the other hand, most working women and men claim their Social Security benefits before the Normal Retirement Age and receive actuarially reduced benefits, suggesting a replacement rate somewhat lower. The fact that new retirees receive an actual median replacement rate of 42 percent of AIME - slightly higher than the level suggested by the policy model - is the net of these two offsetting factors. Second, the earnings records and replacement rates differ sharply by gender. Third, when individuals are combined into households, the median couple with a non-working spouse receives a high replacement rate -58 percent, while couples where both spouses work average 41 percent. This outcome is to be expected in a system that provides a 50-percent spouse's benefit, so that wives' earnings frequently increase the denominator without raising the numerator of the replacement rate. Finally, it is not correct to either ignore housing equity or to annuitize the entire value and add it to the numerator without any adjustment for imputed rent. Taking a comprehensive view of income, the results from the HRS suggest that most of those who retire with private pension coverage have potential replacement rates (assuming all available assets are used to buy annuities) that meet the 70 percent to 75 percent threshold often cited as the amount required to maintain pre-retirement consumption. For those without pensions, the replacement rates fall below the adequacy threshold, and the shortfall can be substantial when pre-retirement earnings are defined in terms of earnings immediately prior to retirement.

\section{THE “REPLACEMENT RATE” CONCEPT}

Replacement rates are used to gauge the extent to which older people can maintain their pre-retirement levels of consumption once they stop working. ${ }^{1}$ The most direct approach would be a comparison of household consumption while working with consumption after retirement. But such data are rarely available. An indirect approach is to

\footnotetext{
${ }^{1}$ Technically people are interested in smoothing marginal utility, not consumption. To the extent that they get pleasure from leisure in retirement, they can maintain overall utility with lower levels of consumption after they stop working. The enjoyment of leisure may explain what the literature calls the "retirement-consumption puzzle" - namely, the fact that consumption appears to drop as people retire. See Bernheim, Skinner and Weinberg 2001, Banks, Blundell and Tanner 1998, and Hurd and Rohwedder 2003.
} 
compare pre- and post-retirement income. ${ }^{2}$ This section briefly reviews what might be considered an adequate level of replacement income and describes some of the conceptual issues involved in constructing replacement rates.

\section{What replacement rate do people need in retirement?}

People clearly need less than their full pre-retirement income to maintain their standard of living once they stop working. One big difference before and after retirement is the extent to which income is taxed. When people are working, their earnings are subject to both Social Security payroll taxes and federal personal income taxes. After retirement, they no longer pay Social Security taxes, and they pay lower federal income taxes because only a portion of Social Security benefits are taxable. Under current law, individuals with less than $\$ 25,000$ and married couples with less than $\$ 32,000$ of "combined income" do not have to pay taxes on their Social Security benefits. Above those thresholds, recipients must pay taxes on either 50 or 85 percent of their benefits. ${ }^{3}$

A second reason why retirees require less than their full pre-retirement income is that they no longer need to save a portion of that income for retirement. In addition to contributing to $401(\mathrm{k})$ plans, many households try to pay off their mortgage before they retire. In retirement, these households no longer need to save and, in fact, can draw on their accumulated reserves. Thus, a greater share of their income is available for spending.

A final factor often mentioned is that work-related expenses, such as clothing and transportation, are either no longer necessary or are much reduced. Although this factor often tops many analysts' lists, it is relatively small compared to taxes and saving.

\footnotetext{
${ }^{2}$ In an extension of the replacement rate approach to test whether people are saving optimally for retirement, two recent studies (Engen, Gale, and Uccello (1999) and Scholz, Seshadri, and Khitatrakun (2004)) compare people's actual behavior with the behavior that comes out of simulation models. In these simulations, people attempt to smooth their consumption over their remaining lives as they are buffeted by shocks to their wages, employment, and health. Because of these shocks, households with very similar characteristics can end up with very different levels of wealth. These simulations have generally produced results where people's actual level of preparedness look very much like the numbers generated by the simulations, suggesting that people respond rationally to life's events.

${ }^{3}$ The percent of Social Security benefits subject to personal income taxation is as follows. Individuals with “combined income" between $\$ 25,000$ and $\$ 34,000$ include 50 percent of benefits; over $\$ 34,000$ they include 85 percent. Couples with "combined income" between $\$ 32,000$ and $\$ 44,000$ include 50 percent of benefits; over $\$ 44,000$ they include 85 percent. Combined income is adjusted gross income as reported on tax forms plus nontaxable interest income plus one half of Social Security benefits.
} 
While all analysts cite the same factors for why retirees need less than their full preretirement income, they employ different approaches to calculating precisely how much less. The RETIRE Project at Georgia State University has been calculating required replacement rates - that is, retirement income as a percent of pre-retirement earnings - for decades. For an array of pre-retirement earnings levels, they calculate federal, state, and local income taxes and Social Security taxes before and after retirement. They also use the Bureau of Labor Statistics Consumer Expenditure Survey to estimate consumer savings and expenditures for different earnings levels. As of 2001, the Project estimated that a couple with an income of $\$ 50,000$ needed 76 percent of pre-retirement earnings to maintain the same level of consumption (Table 1). The same was true for couples earning $\$ 90,000$. Couples earning $\$ 20,000$ needed a higher replacement rate (83 percent), because they save very little before retirement and enjoy less in the way of tax savings.

Another way to determine adequate savings rates is to look at survey data to explore the relationship between replacement rates and retirement satisfaction. The Health and Retirement Study, which will form the basis of the empirical analysis in this paper, asks retirees:

"All in all, would you say that retirement has turned out to be: very satisfying, moderately satisfying, or not satisfying at all?"

Among retired couples, those who answered "very satisfied" or "somewhat satisfied" had a median replacement rate of about 72 percent, while those who said that their retirement was "not at all satisfying" had a median replacement rate of 60 percent. In this exercise, the replacement rate is defined as the ratio of Social Security, pension benefits, and the annuitized value of defined contribution and non-pension financial wealth to average indexed lifetime earnings (including earnings above the Social Security cap) and the return on financial assets. As the following discussion will demons trate, however, replacement rates vary considerably depending on what is included in the numerator and denominator.

Nevertheless, the upshot of the range of studies that have examined the issue is that middle class people need between 70 and 75 percent of their pre-retirement earnings to 
maintain their life style once they stop working. The focus of this study is to determine what people are actually receiving in retirement.

\section{Constructing Replacement Rates}

Retirement income comes from a variety of sources, some in the form of annuities that pay benefits for life and some as lump sums or physical assets that need to be transformed into annuities to determine their contribution to monthly income. Social Security is the primary source of monthly cash income for today's elderly Americans. Social Security monthly benefits replace a portion of "average indexed monthly earnings" (AIME), which is essentially the 35 highest years of earnings indexed to the present by wage growth. ${ }^{4}$ The other source of monthly income is employer-sponsored defined benefit plans. Although pension coverage has shifted toward 401(k) plans, defined benefit plans still dominate the retirement portfolio of today's retirees and those near retirement. These plans typically replace a portion of the worker's "final earnings," generally the worker's annual earnings during the last three or five years of employment, which tend to be the worker's highest earnings with that employer. This study uses both measures of pre-retirement earnings whe $n$ constructing replacement rates. The AIME provides a basis to compare sample estimates with official outcomes published by the Social Security Administration, and the last years of earnings provides a measure of the end-of career standard of living that workers seek to maintain in retirement.

A second consideration is defining when "pre-retirement" ends and retirement begins. With the growth of bridge jobs, it is often impossible to define precisely the work/retirement divide. For this reason, this study focuses on the first year that workers start receiving Social Security benefits. In the case of couples, retirement is defined when both members of the household are receiving benefits.

A third consideration is the unit of analysis. Replacement rates have largely been calculated on an individual worker basis, even though the great majority (roughly 80 percent)

\footnotetext{
${ }^{4}$ In the case of retirement, the AIME is determined in two steps. First, the worker's annual taxable earnings after 1950 are updated, or indexed, to reflect the general earnings level in the indexing year, which is age 60. Earnings in years after 60 are not indexed but instead are counted at their actual value. A worker's earnings prior to age 60 are indexed by multiplying them by the ratio of the average wage in the national economy for the indexing year (the year the worker turns 60) to the corresponding average wage figure for the year to be indexed. Second, the AIME is calculated by taking the highest 35 years of wage-indexed earnings between age 22 and 62 and divid ing that total by the number of months in that period.
} 
of Americans enters retirement as part of a married couple household. The general presentation of replacement rates on an individual worker basis no doubt reflects the fact that Social Security and employer pension benefits are based on individual worker earnings. ${ }^{5}$ This paper also presents individual replacement rates in order to calibrate the estimates from the sample with official SSA outcomes. But households consume on a joint basis, so the paper calculates replacement rates for couples and single-person households.

Finally, the replacement rate depends crucially on the treatment of people's homes. It is impossible to ignore home equity because the homeowner will receive the "imputed rent" generated by the house after retirement just as it does before retirement. Therefore, imputed rent belongs in both the numerator and denominator of the replacement rate. Whether to include the residual value of the house - roughly the amount that could be accessed through a reverse mortgage - is more a question of policy. Some have argued that it should not be included because people hold on to their homes until they are quite old. ${ }^{6}$ On the other had, in the future households may be unable to enjoy the luxury of not tapping residual home equity, so it is useful to see how it affects outcomes.

To calculate replacement rates, this paper uses the Health and Retirement Study (HRS). The HRS is a nationally-representative data set that began in 1992 with about 12,650 individuals from about 7,600 households. ${ }^{7}$ This original survey interviewed people age 5161 and their spouses (regardless of age), and the survey was re-administered in 1994, 1996, 1998, 2000, 2002, and 2004. The HRS contains detailed information on earnings before retirement and on Social Security and pension benefits as well as 401(k) balances and homeownership, and is thus ideal for this study. ${ }^{8}$

\footnotetext{
${ }^{5}$ The initial design of the Social Security program did not include spousal benefits; these benefits were only included in the 1939 legislation. In the case of defined benefit plans, it was not until the Employee Retirement Income Security Act (ERISA) of 1974 that joint-and-survivor pensions became a reasonably common annuity form.

${ }^{6}$ Venti and Wise (2001).

${ }^{7}$ The HRS is conducted by the Institute for Social Research (ISR) at the University of Michigan and is made possible by funding from the National Institute on Aging. More information is available at the ISR website: http://hrsonline.isr.umich.edu/.

${ }^{8}$ See Juster and Suzman (1995) for a detailed overview of the survey.
} 


\section{SOCIAL SECURITY REPLACEMENT RATES FOR INDIVIDUAL WORKERS}

This section covers three issues. It first describes how the Social Security Administration calculates replacement rates for its policy model low, medium, and high earner. It next presents existing evidence to assess the extent to which the policy model replacement rates track those of real-world workers. Finally, it reports individual earned replacement rates for HRS workers and compares them to official SSA replacement rates for new retirees.

\section{Social Security Replacement Rates in the Trustees Report}

The Social Security Trustees Report uses four illustrative cases to present projected benefit amounts and replacement rates under current law. Three of these cases correspond to hypothetical workers with career average earnings equal to a percentage of the "average wage index" for the year prior to retirement - 45 percent for the "Scaled Low Earner;" 100 percent for the "Scaled Medium Earner;" and 160 percent for the "Scaled High Earner." A fourth worker represents someone who has earned the maximum taxable earnings throughout his career. Table 2 summarizes the replacement rates for the hypothetical individuals in 2004, relative to career-average earnings and AIME. The age- 62 replacement rates are particularly relevant, because most participants claim benefits before age 65. As shown in Table 3, 59 percent of women and 53 percent of men in 2003 claimed their Social Security benefits at age 62.

The replacement rates for workers with scaled low, medium, and high earnings are derived from a complicated construction of hypothetical earnings histories. To understand the way today's hypothetical histories are calculated, it is useful to think about the way they were calculated prior to 2001. Until that time, the hypothetical workers were assumed to enter the labor force at age 22, remain constantly employed until age 65 , and earn the "average wage index (AWI)," or some percentage thereof, throughout their working careers.

The average wage index is intended to measure the average wage in the economy. ${ }^{9}$ As shown in Figure 1, the AWI tracks the average for all wage and salary workers over the

\footnotetext{
${ }^{9}$ Although the average wage index is intended to measure average wages, it is not calculated by dividing annual total wages by the number of workers. Rather, the benchmark is the average of all wages up to the taxable maximum earnings between 1973 and 1977. That is, for the period 1973-77, the AWI is simply the sum of taxable earnings reported to SSA during the first quarter of the year divided by the number of taxpaying
} 
period 1951-2003, and, as expected, the average wage for men lies above the overall index, and the average for women below. ${ }^{10}$

Although the AWI tracks the real-world average, the "steady earner" assumption bore little relation to reality. Young workers, for example, typically earn less than middle-age or older workers, reflecting their modest levels of job tenure and skill. As workers age, their earnings tend to rise in line with their increased experience and ability. At around age 50, earnings tend to decline as skills erode or workers reduce their hours. The evolution of earnings over a worker's career is of no concern in the calculation of Social Security benefits (assuming it has no effect AIME). But the evolution of earnings is quite important for the analysis of individual accounts and the "money's worth" of Social Security benefits (as contributions made early on are significantly more important than those made later in life). As these issues gained prominence, the SSA created earnings profiles that more accurately defined earnings across the work span. ${ }^{11}$

Figures $2 \mathrm{a}$ and $2 \mathrm{~b}$ show real - inflation-adjusted - earnings for hypothetical workers using the steady earnings profile and the scaled steady earnings profile. The SSA now uses

workers and multiplied by four to get an annual figure. The fact that it did not include earnings above the taxable maximum was not viewed as particularly important since few workers earned over the maximum taxable earnings in the first quarter. In the years after 1977, the AWI is adjusted each year in line with the growth of all earnings, as reported on the IRS W-2 forms. For the years before 1973, the annual percentage changes were derived from first-quarter data from a 1-percent sample of employer-employee records collected during 1957-1972, known as the Longitudinal Employee-Employer Data (LEED). These 1957-1972 changes were then used to index the AWI level backwards from 1973. Before 1957, LEED data were not available, so SSA used a 0.1 percent sample of earnings records (up to the taxable cap) collected for 1951-1956. Changes from this sample were used to index the AWI back from 1957 (See Donkar 1981).

${ }^{10}$ A recent study by Au, Mitchell, and Phillips (2004) concludes that average wage and salary income consistently exceeds the AWI. This conclusion is the result of inclu ding only full-time, year-round workers in measuring the increase in average wage and salary income. By including part-time and non-year-round workers, the average wage and salary income more closely tracks the AWI. This broader universe reflects the concept adopted by the Social Security Administration in constructing the AWI.

${ }^{11}$ Scaled factors determine the shape of the hypothetical wage profiles. To obtain these factors, Social Security uses a sample of workers with some OSADI taxable earnings during their lifetime, and restricts the analysis to those who are fully insured. Out of this sample, SSA focuses on the most recent 10 years of earnings, including years of zero earnings. To compute the scaled factors, SSA divides earnings for each individual by the AWI for every year, and then groups the ratios by age. The resulting factor for the age group is the average of the individual observations. This methodology produces the age-specific raw scaled factors, which turn out to be less than 1 for each age and peak at age $48(0.944)$. The next step is to adjust the raw scaled factors to make them consistent with the AIME derived for low, median, and high earners based on the steady earnings profiles used before 2001. (As a note, SSA moderates the scale factors for ages 62-64 because the original numbers showed a sharp rise at that age; instead it holds earnings constant in nominal terms from age 62 on.) The third step is to apply the modified scale factors to the AWI in each year to derive scaled earnings. The first set of published scaled factors used earnings data from 1988-97, but these factors are updated annually using the ten most recent years of data. 
"scaled earnings" in its policy model, with earnings levels set so that their AIMEs equal the benchmark 45 percent, 100 percent, and 160 percent of national average earnings for the low, "medium," and high earners, respectively. Again, for calculating indexed lifetime earnings the pattern of earnings is not important. The question is whether the average indexed monthly earnings based on the average wage index match up with the earnings experience of actual workers.

\section{How Representative Are the Hypothetical Workers?}

The policy model used to construct hypothetical Social Security replacement rates is clearly a simplification of real world patterns. It assumes that the "medium" worker enters the labor force at age 22, remains constantly employed until age 65, and has career average earnings equal to the national average wage for the year prior to retirement. But most workers, especially married women, have significant breaks in employment, either in unemployment or time spent out of the work force. And most workers claim Social Security benefits well before the Normal Retirement Age.

A straightforward test of the accuracy of the policy model earnings and replacement rates is to compare these estimates with actual initial benefits received by real-world workers. The policy model has the "medium earner" claiming benefits in 2003 receiving $\$ 13,841$ if he retired at age 65, and roughly 80 percent of that amount, or $\$ 11,051$, if he retired at age 62 . Assume that 60 percent of "medium earners" claim benefits at age 62 and 40 percent at age 65 , the weighted average benefit for "medium earners" in 2003 projected by the policy model would be $\$ 12,167$. For all workers who claimed benefits in 2003 , the actual average benefit amounted to $\$ 11,276$ - roughly $\$ 900$ less than the hypothetical amount. ${ }^{12}$ Thus, the simplest calculation suggests that the policy-model benefit projections are somewhat high, which means - given the progressive structure of the Social Security benefit formula - that the policy model replacement rate projections are somewhat low.

Confirming evidence that replacement rates for real-world workers are greater than those for the "medium earner" comes from a study by Social Security's Office of the Actuary

\footnotetext{
${ }^{12}$ A more precise calculation yields a similar result. For hypothetical "medium scaled workers" retiring at ages 62 to 70 in 2003, the estimated annual scheduled benefit at normal retirement age is multiplied by the actuarial adjustment - from 0.77 for age 62 to 1.275 for age 70 . If weighted by the age distribution of initial Social Security benefit a wards for all workers (Table 2), the resulting benefit in 2003 would be $\$ 12,242$.
} 
(Clingman and Nichols 2004). The SSA actuaries compare the primary insurance amount (PIA) for the policy-model workers with the PIAs for workers retiring in 2003, using a 1percent sample of Social Security Administrative records. The PIA is the benefit a person would receive at the normal retirement age, neither reduced for early retirement nor increased for later retirement. ${ }^{13}$

The actuaries find that the policy model somewhat overestimates the PIA of reat world workers, implying that it underestimates actual Social Security replacement rates. For example, if the SSA policy model "medium worker" is taken to represent the median beneficiary, 50 percent of beneficiaries would have lower PIAs and 50 percent higher. Their calculations show, however, that 59 percent of workers have a lower PIA (Table 4). This result is the net of dramatically different patterns for men and women. Only 37 percent of men have a PIA below that for the hypothetical "medium earner." In contrast, 83 percent of women fall below. This finding suggests that the median male worker has a lower Social Security replacement rate than the policy-model "medium earner," and the median female worker a higher replacement rate. ${ }^{14}$

A second study (Au, Mitchell, and Phillips, 2004), using the 1992 wave of the HRS, also finds that the median wage of actual workers is lower, and the median Social Security replacement rate higher, than figures generated SSA's policy model. ${ }^{15}$ Figure 3 replicates the results reported in the study for the average of the middle 10 percent of earnings of the HRS

\footnotetext{
${ }^{13}$ Calculating the PIA involves three steps. First, a worker's previous earnings are restated in terms of today's wages by indexing past earnings to wage growth. Second, earnings for the highest 35 years are then averaged and divided by 12 to calculate Average Indexed Monthly Earnings (AIME). Finally, the PIA is the sum of three separate percentages that are applied to portions of the AIME. The portions depend on the year in which a person reaches age 62. Specifically, for workers first becoming eligible for benefits in 2004, their PIA was the sum of:

- 90 percent of the worker's first $\$ 612$ of AIME, plus

- 32 percent of AIME between $\$ 612$ and $\$ 3,689$, plus

- 15 percent of any AIME in excess of \$3,689.

This PIA is continually recalculated so long as the individual remains employed; and is indexed to prices from age 62 .

${ }^{14}$ In fact, the median male worker looks very much like the "medium earner." For an explanation of the discrepancy between the Clingman and Nichols results and actual Social Security outcomes, see footnote 20.

15 The HRS has data on earnings up to the taxable maximum for the period 1950-91 and W-2 earnings from 1980 to 1991, making it possible for the authors to construct total labor income for the later period. For the period prior to 1980, the authors estimate year specific real earnings for each worker with capped earnings based on age, own and parents education, race, and sex.
} 
cohort born in 1936. ${ }^{16}$ Limiting the HRS sample to those who were fully insured makes the real world example more comparable to that generated by the policy model. Nevertheless, median HRS earnings fall below the earnings of the policy model "medium earner."

Dividing the sample by gender (not included in the original study) reveals the same pattern discussed above - namely, median earnings for men exceed those of the "medium earner" and for women fall below. Again, the primary reason for the difference is that the hypothetical construct does not account for years of zero earnings, while real-world workers do experience unemployment, and in the case of women, drop out of the labor force to care for children. ${ }^{17}$

Third, a 1999 study (Bosworth, Burtless and Steuerle 1999) included a comparison of earnings from the so-called MINT model with those from the SSA policy model. It finds that SSA's median worker exceeded average indexed monthly earnings by 32 percent for male workers and 57 percent for female workers. The most likely reason this study shows a larger discrepancy than other studies is that the sample of workers is not limited to those who are fully insured.

A final study - the Performance and Accountability Report also undertaken by the Social Security Administration - provides some evidence on why replacement rates for realworld workers might exceed those suggested by the hypothetical construct. ${ }^{18}$ It reports the average number of years of zero earnings since age 22 for both men and women workers who have recently claimed benefits. Men average 6 years of zero earnings, and women 13 years. For men, years with zero earnings should have a minimal impact on their earnings history relative to the hypothetical worker. That is, new retirees have a potential for 40 years of earnings between age 22 and 62, from which SSA selects the highest 35 years for the benefit calculation. On average, male workers will have 34 years of nonzero earnings. Women, on the other hand, average 13 years of zero earnings. So even their 35 highest will include an average of eight years of zeros.

\footnotetext{
16 The median 10 percent is the weighted mean of data points between the $45^{\text {th }}$ and $55^{\text {th }}$ percentiles for each cohort. This produces a measure similar to the median.

17 The labor force participation rate for married women with children under 3 years is only 56.5 percent, but labor force participation rises to 81.2 percent for those with children age 14-17 (U.S. Bureau of the Census. 2005. Table No. 580.

18 The data come from a 1 percent of the Continuous Work History Sample supplemented with information from the Master Earnings File for persons retiring in 1999-2003.
} 
The Performance and Accountability Report also provides replacement rates for both men and women who have just claimed benefits (Table 6). The median replacement rate is 42 percent, which, at first, looks identical to that for the "medium earner." But the Performance and Accountability Report calculates replacement rates relative to AIMEs while the "medium earner" uses career-average earnings indexed to the year prior to retirement as the base. Shifting to AIME as the denominator, the hypothetical worker has a replacement rate of about 48 percent of AIME. ${ }^{19}$ On the other hand, the "medium earner" retires at age 65, while, as noted, most workers retire early and therefore receive actuarially reduced benefits. Given the actual retirement patterns of real-world workers, the weighted average replacement rate for the medium earner would be about 40 percent of AIME $(0.40 \times 47.7$ percent $+0.60 \times 34.7$ percent), slightly below the reported 42 percent for actual retirees. The replacement rate for new male retirees (37 percent to AIME) is similar to that of the hypothetical worker retiring at age 62 (35 to AIME). This is not a surprising outcome given that the AWI has tracked the median wage for men very closely (Figure 4), that men tend to have few years of zero earnings, and that most men retire at age $62 .{ }^{20}$ It is interesting the extent to which men's wages still dominate the earnings picture (Figure 5). What brings

\footnotetext{
${ }^{19}$ The AIME of the "medium earner" can be estimated from the published level of benefits $(\$ 13,814$ in 2003$)$, by applying the inverse of the Social Security Benefit Formula. First, the annual benefit is divided by 12 and the actuarial adjustment to obtain the PIA $(13,814 /(12 * 0.989)=1,164)$. Second, this PIA is adjusted to take out the cost-of-living adjustments from 2000 to 2003, which produces 1,081. Third, the age 62 (year 2000) bend points are applied to calculate the AIME that generates 1,081, resulting in an AIME of 2,417 (531+ [1,081-(0.9 $\mathrm{x} 531)] / 0.32=2,417)$. Last, this number is multiplied by 12 to obtain the AIME annual denominator $(29,000)$. To estimate the AIME-based replacement rate, the benefit is divided by the new base resulting in 47.7 percent $(13,814 / 28,998=0.477)$, which represents the age-65 AIME-based replacement rate for a hypothetical "medium earner" retiring at age 65 in 2003. To estimate the age 62 AIME-based replacement rate, a similar procedure is followed, starting from the estimated benefit of the hypothetical sacelaed earner retiring at age 62 in 2003, modifying the actuarial and COLA adjustments. This produces an AIME-bassed replacement rate of 34.7. For more details about the benefit formulas see Social Security Administration 2005, http://www.ssa.gov/OACT/COLA/AWI.html, http://www.ssa.gov/OACT/TR/TR05/tr05.pdf, http://www.ssa.gov/finance/2004/Full_FY04_PAR.pdf.

${ }^{20}$ This finding appears to contradict the Clingman and Nichols (2004) conclusion that 37 percent of males have a lower PIA than that of the "medium earner" who retires at age 65 in 2003 . The explanation for this apparent inconsistency is that the Clingman and Nichols study includes all workers retiring in 2003, regardless of their age of retirement. Even if the median male looks like the "medium earner" in each cohort, the PIA of the median retired worker will be higher than that of the "medium earner" when the 60 percent who retire at age 62 are put together with the 40 percent who retire at age 65 . The reason is that - in a world of rising real wages those retiring at age 62 will have enjoyed a higher level of earnings on average. With a wage-indexed benefit formula, these higher earnings will translate into higher PIAs, which will raise the median PIA for the combined group. As a result, less than 50 percent of male workers will fall below the hypothetical median. To be consistent, one should compare the PIAs of actual retirees with those from a hypothetical worker of the same cohort that retires in the same year.
} 
down average earnings is the substantial number of zeros in the earnings histories for women, which leaves them with low earnings and a higher replacement rate (52 percent).

A consistent story thus emerges from this survey of empirical studies. Although the average wage index is a peculiar construct, it does closely follow average wages for the whole economy. Not surprisingly, average wages for men are higher than the average wage index and for women are lower. But, in the aggregate, the index is reasonable. The question is whether the average wage index reflects the earnings for the typical worker. Here the answer appears to be that, on average, real-world earnings of fully insured workers fall somewhat below the index. Thus, policy model projections of the replacement rate for the "medium earner" - based on the assumption that "medium earner" averages 100 percent of the average wage index over his lifetime - understates actual replacement rates. The discrepancy arises because the policy-model workers are steady earners, whereas real-world individuals have periods of unemployment and take out time to care for young children. (Interestingly, and probably coincidently, median earnings of men have closely tracked the average wage index. This fact, together with the fact that men have few years of zero earnings, means that the medium scaled earner does reflect the earnings history and benefit and replacement rate outcomes for the typical male worker. But the relevant replacement rate is not the oft-reported 42 percent, but rather 35 percent because the typical man retires well before age 65.)

\section{HRS Replacement Rates for New Retired-Worker Beneficiaries}

To test whether the HRS provides a pic ture consistent with that reported by SSA, this section replicates the tables provided in the SSA's Performance and Accountability Report described above. This exercise involves looking in various waves of the HRS at individuals age 62 and over and calculating the number of years with zero earnings and benefits as a percent of AIME in the year when the worker first claims benefits. The specific calculations for the HRS are as follows:

- Retirement age. The retirement age comes from the self-reported year when the respondent first received Social Security Benefits (rassageb from RAND-HRS). For those respondents with missing values, retirement ages are obtained from the retirement year indicator from RAND-HRS (r*retyr). Individuals who retire before age 62 because 
of disability (radiget) are excluded from the final sample. Early retirees who can not be identified as disabled are randomly assigned a retirement age based on the pattern of retirement by gender.

- AIME, PIA, and Social Security benefit. Social Security earnings are taken from the restricted data set of the HRS Covered Earnings Records for the years 1951-1991. After 1991, earnings are calculated from self-reported data in the HRS and capped at the maximum taxable level. The earnings history is then used to construct the AIME The PIA and Social Security benefit are estimated using the Social Security benefit formula.

Table 5 reports the average number of years with zero earnings from age 22 to the last year before collecting benefits. For women, the figures look very close between the two samples, with the average around 13 years. In the case of men, the HRS shows about half a year less of zero earnings than the SSA report. Overall, the picture is quite similar between the two samples.

Table 6 presents median earned replacement rates - replacement rates based on the individual's earnings record - of newly retired-worker beneficiaries for the SSA sample and the HRS. Again, the results are remarkably close. The median replacement rate for the total population in the two samples is about 42 percent. $^{21}$ This overall rate is the composite of a median replacement rate of 37 percent for men and about 52 percent for women.

Finally, Table 7 shows median replacement rates for the two samples by earnings quintile. The HRS results closely track those from the Performance and Accountability Report. The result is not too surprising, since the HRS calculations are based on SSA earnings data between 1951 and 1991. But after 1991, earnings are self reported, introducing the potential for some discrepancy between the two sources. That little exists is comforting.

\section{HOUSEHOLD REPLACEMENT RATES INCLUDING PENSIONS AND OTHER ASSETS}

Having verified that the HRS produces earnings records and replacement rates for individuals very close to the official SSA numbers, this section moves the analysis forward in three steps. First, the HRS population is reassembled into households and Social Security

\footnotetext{
${ }^{21}$ Again, this 42 percent should not be confused with the 42 percent reported in the Trustees Report for the worker with medium scaled earnings retiring at age 65 , because the majority of reat-world men and women claim benefits well before the normal retirement age.
} 
replacement rates are estimated for the household unit. Since retirement income is limited to Social Security, the earnings base continues to be AIME. The next step is to add pensions and other assets to the numerator of the replacement rate calculations, and to expand the denominator to include earnings above the cap and the return on non-pension financial assets. The final step in this section is to experiment with denominators other than the AIME, such as the highest five years of earnings out of the last ten years just before retirement. The next section then addresses the appropriate treatment of housing in replacement rate calculations.

\section{Household Social Security Replacement Rates}

The earned replacement rates for individuals provided in SSA's Performance and Accountability Report offer a benchmark against which to assess the reasonableness of the household numbers. For example, SSA shows the median male earned replacement rate is about 37 percent and the median female earned replacement rate is about 52 percent. The average for single people, assuming that single people have similar earnings histories as married people, should be a weighted average of the two. Since women account for 70 percent of single workers covered by Social Security, a first approximation of the combined replacement rate for single workers should be 47 percent.

Couples consist of two types - those with one worker where the spouse has an AIME of zero and those where both spouses work and both have a positive AIME. Again assuming that single people have similar earnings histories as married people, for couples in which the wife has no earnings record of her own, one would expect a replacement rate of 150 percent of 37 percent or 55.5 percent. In couples where both spouses have an earnings record, two adjustments occur. First, the wife's earnings record goes into the denominator. Second, the wife's benefit, which is the greater of 50 percent of her husband's benefit or the benefit based on her own earnings record, goes into the numerator. With the information that 1) the median earned replacement rate for men is 37 percent and for women 52 percent, and 2) according to the HRS the median ratio of wife's to husband's AIME is 42 percent, it is possible to approximate the replacement rate for the median two-earner couple. ${ }^{22}$ That is, for a two-earner median couple the expected replacement rate is equal to:

\footnotetext{
22 The following exercise assumes that the median man is married to the median woman. This is a strong assumption, but the equation is used only as a gauge for expected outcomes.
} 


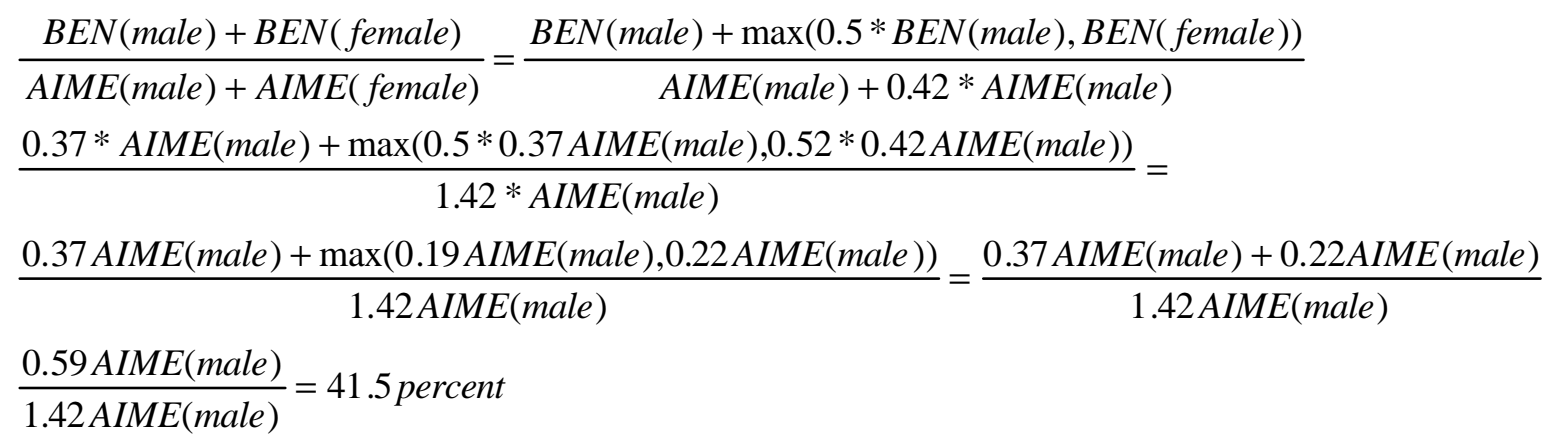

The next step is to calculate actual replacement rates for households using the HRS. The derivation of the retirement age and Social Security AIME, PIA, and bene fit are described above. This step involves aggregating individual information into a household format. In the case of single-person households, replacement rates are simply the ratio of benefits to AIME in the year the individual retires. For couples, replacement rates are estimated in the first year in which both members of the household are retired. In the case where both members of the couple are already retired, the procedure is to adjust the AIME and PIA for each spouse for inflation in order to report them for a common year and then divide the couple's combined benefits by the couple's combined AIME. In the case where only one spouse is retired, the working spouse - generally the woman - is randomly assigned a retirement age based on the female pattern of retirement. Since the replacement rate is calculated on the assumption that both spouses are retired, earnings are eliminated from the numerator of the replacement rate calculation. Eliminating earnings presents a more realistic picture of the income replacement the couple will enjoy over their retirement span.

Replacement rates for households as calculated from the HRS data and as predicted from SSA's Performance and Accountability Report are shown in Table 8. According to the HRS, couples receive Social Security benefits equal to 44 percent of their combined AIME. The replacement rate is sharply higher, however, for those couples where only one spouse works - 58 percent versus 41 percent for couples where both spouses have a positive AIME This outcome is virtually inevitable in a system that provides a 50-percent spouse's benefit. As women go to work, they increase the denominator with their AIME but often fail to increase the numerator. Where the husband is the median worker, for example, the working wife does not add to the numerator until her earnings exceed 36 percent of her husband's. Since more than 40 percent of working wives earn less than 36 percent of their husband's earnings, working wives often reduce household Social Security replacement rates (Table 9). 
The median Social Security replacement rate for single individuals is 45 percent very close to that for couples (Table 8). The average, however, is the result of a replacement rate of 39 percent for single men and 49 percent for single women. This difference by gender simply reflects the fact that men on average earn more than their female counterparts. The replacement rate for single women (49 percent) is lower than that for all women (52 percent) published in SSA's Performance and Accountability Report. The discrepancy reflects the fact that single women, who must depend on themselves for support, earn more on average than married women Indeed, the HRS shows that single women have an AIME equal to 1.2 times that of married women.

Table 10 presents replacement rates by quintiles of AIME for couples and for single individuals. For single-person households, replacement rates range from 72 percent to 32 percent, similar to the 72 to 30 range of individual earned replacement rates shown in Table 7. For couples, however, the range of actual replacement rates (63 percent to 33 percent) narrows considerably. The high earned replacement rates disappear once people are combined into couples because the primary recipients of the low AIMEs and high earned replacement rates are married women(Table 11). When married women are paired with their husbands, who tend to have higher AIMEs and lower earned replacement rates, the range of replacement rates narrows.

The story so far is that Social Security benefits provide on average about 43 percent of household AIME to both couples and single individuals. The range of actual Social Security replacement rates is narrower, however, for couples than for individual workers.

\section{Household Replacement Rates with Pensions and Returns on Financial Assets}

Up to this point, the analysis has focused only on Social Security. This section expands retirement income sources to include benefits from defined benefit plans and the annuitized value of defined contribution assets and other financial assets.

Defined benefit wealth is based on the Peticolas-Steinmeier numbers posted on the HRS website; these numbers are derived from the restricted pension data provided by the employer. ${ }^{23}$ Defined contribution wealth is based on self-reported estimates for all waves,

\footnotetext{
23 For ages 55, 62 and 65 the values are taken right from the website. Values for other years are a weighted average of the reported data.
} 
where available. If not available, values are calculated from reported employee and employer contributions plus accruals. ${ }^{24}$ The resulting numbers for both defined contribution and defined benefit plans are comparable to those reported by Gustman and Steinmeier (1999). Financial wealth comes from the RAND subset of the HRS and includes stocks, bonds, savings and checking accounts, certificates of deposit, and any other account, minus non-housing debt.

As before, household replacement rates are estimated at the first year in which both members of the household are retired. This is done by estimating the annuity value for defined benefit and defined contribution pensions for each member of the household starting at his or her retirement age and then projecting this value to the year in which the second member of the household retires. For financial wealth, which is a household rather than an individual asset, the value is annuitized starting at the first year in which both members of the household are retired. To make the numbers comparable among individuals, all figures are stated in 2002 dollars.

IRAs complicate the analysis because most of the assets in these accounts are rollovers from $401(\mathrm{k})$ plans and the earnings on those rollovers. ${ }^{25}$ IRAs are handled in the subsequent analysis of replacement rates as follows. Pension coverage is defined excluding IRAs. That is, individuals must have participated in an employer-sponsored defined benefit or defined contribution plan to be classified as having pension coverage. In terms of the allocation of IRA assets, for those with pension coverage IRA balances are combined with defined contribution assets. For those without pension coverage, IRA assets are included in total financial wealth. ${ }^{26}$

Table 12 shows the impact of pension coverage and financial assets on the replacement rates of couples and single individuals. The first panel of Table 12 uses a denominator of AIME As one would expect, those households without pension coverage tend to have lower earnings and higher Social Security replacement rates than those with coverage -48 percent versus 42 percent in the case of couples and 49 versus 40 in the case of

\footnotetext{
${ }^{24}$ A small fraction (less than two percent) of respondents in the HRS sample indicated having a pension plan with both defined benefit and defined contribution characteristics. Data on defined contribution assets in these "combined" plans were oftentimes not available, so they are grouped together with defined benefit plans.

${ }^{25}$ Increasingly, of course, IRA accumulations will also include rollovers from defined benefit and cash balance plans.

${ }^{26}$ Median defined contribution wealth for those with coverage is $\$ 34,244$ (excluding IRA as sets) and median defined benefit wealth is $\$ 132,505$. These results are fully consistent with those from other studies.
} 
singles. Adding pensions produces a median replacement of 70 in the case of couples and 76 percent in the case of single individuals. ${ }^{27}$ Adding the annuitized value of financial assets brings the median replacement rate for both couples and single-person households with pensions to more than 80 percent. This number compares to about 60 percent for households without pension coverage.

These results are interesting in that they produce a reasonable story regarding the progression in replacement rates as additional sources of retirement income are added to Social Security. The replacement rates are not economically meaningful, however, because the denominator - AIME - is based on earnings below Social Security's taxable maximum and it excludes other sources of pre-retirement income. In order to provide a more relevant picture, the second and third panels of Table 12 include earnings above the cap and earnings immediately prior to retirement respectively. ${ }^{28}$ Both panels also include a measure of the pre-retirement income from financial assets.

Adding earnings above the cap reduces the replacement rates for couples by about 6 percentage points. For single individuals, expanding the definition of pre-retirement has a trivial effect, reducing replacement rates by about two percentage points. In other words, median replacement rates including pensions and annuitized defined contribution and financial wealth in the numerator and a comprehensive measure of wage-indexed earnings in the denominator, are 55 percent for couples and 58 percent for single-person households without pensions and 74 for couples and 86 percent for single-person households with pensions.

\section{Household Replacement Rates Based on Earnings Just Prior to Retirement}

\footnotetext{
${ }^{27}$ Since the figures in Table 12 are medians, it is not possible to add them together to derive the combined replacement rates. Nevertheless, the numbers tell a consistent story.

${ }^{28}$ The restricted data SSAEAR3.DA contain the covered earning records for individual workers between 1951 and 1991. Since earnings are top-coded at the maximum taxable earnings for each year, the calculation of actual career-average earnings for many individuals require imputations. From the final sample of individuals used on this paper, about a third of those covered require imputations for at least one year of earnings. To impute earnings for those at the ma ximum taxable earnings, a random-effects, Tobit regression is applied to all of the available data, with earnings as the dependent variable. The explanatory variables include age, age square, categorical variables for gender, college degree and race, and dummies each decade. For individuals below the cap, their actual earnings are used. For individuals with coded earnings at the cap, their earnings are imputed using the regression results to estimate the expected earnings for each individual based on the explanatory variables, conditional on the fact that their earnings were at or above the cap.
} 
Up to now the analysis has been based on the concept of average lifetime earnings, either excluding or including earnings above the cap. One could argue that households are more interested in replacing the earnings they enjoy immediately prior to retirement. The third panel of Table 12 reports replacement rates where pre-retirement earnings are defined as the highest five out of the last ten years just before retirement. This expanded definition of the denominator reduces household replacement rates by about 10 percentage points. For households with pensions, median replacement rates are 60 percent for couples and 67 for single individuals. Using this more immediate definition of pre-retirement earnings produces replacement rates of about 45 percent for those without pensions.

In sum, as additional sources of retirement income are included, those with pension coverage appear increasingly well prepared; those without pensions do not fare as well. But the level of replacement rates - which ranges from 60 to 80 percent for those with pensions, and 45 to 60 percent for households not covered by a pension plan — varies significantly depending on the definition of pre-retirement earnings

\section{THE HOUSING ISSUE}

The replacement rates calculated up to this point have excluded any recognition of housing. Yet for most families, their house is their largest non-pension asset (Table 13). The extent to which the house or some part thereof should be included in replacement rate calculations has been the source of considerable controversy. Some authors have thrown up their hands and presented numbers including zero, 50 percent, or 100 percent of home equity as contributing to earnings replacement. ${ }^{29}$ The implication is that these are equally good options, and the choice rests with the reader. This section argues that theory and practicality suggest a more precise treatment of home equity. Specifically, the entire value of home equity - consisting of a) the present discounted value of imputed rent over the life of the household and b) the residual value accessible (in theory at least) through a reverse mortgage

\footnotetext{
${ }^{29}$ The Congressional Budget Office (1993) includes housing wealth in the set of assets that can be used to finance retirement. Moore and Mitchell (2000) also include housing wealth with other wealth. On the other hand, Bernheim (1992) in considering whether the baby boom generation is preparing adequately for retirement excludes housing wealth. Those letting the reader decide include Engen, Gale and Uccello (1999) who offer zero, 50 percent, and 100 percent of housing equity as options and Gustman and Steinmeier (1999) who conduct their analyses using zero and 100 percent of home equity.
} 
- should be considered available for consumption in retirement. For consistency, however, the value of imputed rent enjoyed before retirement belongs in the denominator of the replacement rate calculation.

\section{Imputed Rent Consumed Over the Life of the Household}

The argument for including imputed rent as part of retirement income is that it will be used to support retirement consumption. Thus, the monthly value of this imputed rent should be incorporated in the numerator of the replacement rate. For consistency, it should also be included in the denominator since the household was receiving imputed rent as part of its income before retirement. This argument implies that "zero" cannot be the right amount of housing wealth available to support consumption in retirement.

Arguing that the imputed rent should be counted as part of pre-retirement income raises the question whether the return on other assets should also be included. Consistency would require that the return on financial assets, the increment in defined benefit wealth, and the employer contribution and return on 401(k) assets also appear in the denominator of replacement rate calculations. In practice, however, the increment to pension wealth probably does not enter household pre-retirement consumption decisions and therefore does belong in the measure of pre-retirement income. ${ }^{30}$ Income from non-pension financial assets - small for most households - is readily accessible to the household and probably is included in the denominator of replacement rates throughout this study.

Including imputed rent in the replacement rate calculation requires determining rents as a percent of home prices and the portion of imputed rent that will be received and consumed in retirement. Analogous to equity valuation, in which the future flow of dividends determines the current price of the stock, the current value of a house should equal the present discounted value of the future rents. For example, the value of a house with an annual rent of $\$ 10,000$ to perpetuity should be priced at $\$ 333,333$ when valued at a 3 percent real discount rate.

\footnotetext{
${ }^{30}$ This may overstate the case, because households could react to the buildup in their $401(\mathrm{k})$ plans by saving less and increasing their consumption. For the HRS cohort, however, this effect is small since defined benefit plans dominate the pension landscape. It is much harder to make a persuasive case that households consider accretion in their defined benefit plan as part of annual income.
} 


$$
P_{o}=\sum_{1}^{\infty} \frac{d_{1}}{(1+r)^{i}} \approx \frac{d_{1}}{r}=\frac{10,000}{0.03}=333,333
$$

But house prices - and rents - are likely to appreciate over time. A simple extension of the basic dividend discount model suggests that a house with an annual rent of $\$ 10,000$ and an annual appreciation of 1 percent should be priced at about $\$ 500,000$ when valued at a 3 percent real discount rate.

$$
P_{o}=\sum_{1}^{\infty} \frac{d_{0}(1+g)^{i}}{(1+r)^{i}} \approx \frac{d_{0}(1+g)}{r-g}=\frac{10,000(1+0.01)}{0.03-0.01}=\frac{10,100}{0.03-0.01}=505,000
$$

This equation also indicates that, at any point of time, rents should be about 2 percent of the value of the house.

$$
\frac{d_{i}}{P_{i}}=\frac{d_{0}}{P_{0}}=\frac{d_{0}}{\frac{d_{0}(1+g)}{r-g}}=\frac{r-g}{1+g}=\frac{0.03-0.01}{1.01}=1.98 \%
$$

But the results are very sensitive to the assumption about the discount rate and the rate of appreciation. Table 14 shows that increasing the discount rate significantly raises the rental rate, while increasing the appreciation rate lowers it.

The portion of housing equity that will be received as income (and consumed) in retirement can be estimated by splitting the present value of the house in two parts: the rents to be received from retirement (time 0 ) until death (time $\mathrm{T}$ ) plus the remaining rents after the household dies:

$$
P_{o}=\sum_{1}^{\infty} \frac{d_{0}(1+g)^{i}}{(1+r)^{i}}=\sum_{1}^{T} \frac{d_{0}(1+g)^{i}}{(1+r)^{i}}+\sum_{T+1}^{\infty} \frac{d_{0}(1+g)^{i}}{(1+r)^{i}}
$$

At time $\mathrm{T}$, the residual value can be expressed as

$$
\operatorname{residual}(T)=\sum_{1}^{\infty} \frac{d_{T}(1+g)^{i}}{(1+r)^{i}} \approx \frac{d_{T}(1+g)}{r-g}
$$

And this can be discounted to time 0 using the discount rate,

$$
\operatorname{residual}(0)=\sum_{T+1}^{\infty} \frac{d_{0}(1+g)^{i}}{(1+r)^{i}}=\frac{\sum_{1}^{\infty} \frac{d_{T}(1+g)^{i}}{(1+r)^{i}}}{(1+r)^{T}} \approx \frac{\frac{d_{T}(1+g)}{r-g}}{(1+r)^{T}}=\frac{\frac{d_{0}(1+g)^{T}(1+g)}{r-g}}{(1+r)^{T}}
$$

Then, the amount to be consumed by households during their lifetime as a proportion of the total value of the house equals : 


$$
\frac{\sum_{1}^{T} \frac{d_{0}(1+g)^{i}}{(1+r)^{i}}}{\sum_{1}^{\infty} \frac{d_{0}(1+g)^{i}}{(1+r)^{i}}}=1-\frac{\sum_{T+1}^{\infty} \frac{d_{0}(1+g)^{i}}{(1+r)^{i}}}{\sum_{1}^{\infty} \frac{d_{0}(1+g)^{i}}{(1+r)^{i}}}=1-\left(\frac{1+g}{1+r}\right)^{T}
$$

The relationship means that for a 1 percent real house appreciation, 3 percent real discount rate, and a joint household life expectancy of about 25 years at retirement, ${ }^{31}$ the portion of the house to be consumed as imputed rent is about 40 percent of the total value.

$$
1-\frac{(1+g)^{T}}{(1+r)^{T}}=1-\left(\frac{1+g}{1+r}\right)^{T}=1-\left(\frac{1+0.01}{1+0.03}\right)^{25}=1-0.60 \approx 0.40
$$

Again, the results are sensitive to both the discount rate and the rate of appreciation of house equity. The 3 percent real rate is close to a risk free rate; rates of 5 to 6 percent may more closely reflect the risk associated with housing. ${ }^{32}$ For example, the ratio of "space rent from the National Income and Product Accounts to the stock of housing report in the Flow of Funds has averaged about 6 percent (Figure 6). Thus, the following analysis assumes that imputed rent consumed over the life of the household equals 70 percent, which is based on a 6 percent discount rate and a 1 percent appreciation rate (Table 15).

\section{Residual Value of the House}

\footnotetext{
${ }^{31}$ A household with a 65 year-old husband and 62 year-old wife has a joint-life expectancy of 24.51 years The joint life expectancy is used for ease of exposition. A more careful calculation should include the annual survival probabilities combined to the discount rate. For the combinations of appreciation rate and discount rate presented in the Tables 14 and 15, both methodologies generate similar results.

${ }^{32}$ Estimates of imputed rent appear to be much higher than that implied by a 3 percent discount rate. One measure is simply the annual imputed space rent reported in the NIPA tables divided by the gross household real estate from the Federal Reserve's Flow of Funds. Since 1980, the percentage has ranged from 6.7 to 5.6 percent, averaging around 6.25. The estimate for imputed rent reported in the NIPA is measured using census and CPI data on comparable rental units. In a recent paper, Crone, Nakamura, and Voith (2004) estimate that the capitalization rate on owner occupied housing averages 9.6 percent. The authors use a hedonic regression that treats the home like a bundle of goods (i.e. an air conditioner, a full bathroom, and a bedroom) to estimate the value of the home and the capitalization rate. This capitalization rate includes not only the imputed rent observable in the NIPA tables, but other factors like advantages in taxation, the physical limitations of converting rentals to owner-occupied (and visa-versa), the risk of increases in rent, expected appreciation, and appeal of ownership, all of which make home ownership more valuable than the observable rental price. Another study - Flavin and Yamashita (1998) - also attempt to construct a comprehensive estimate of the return to homeownership and report a figure of 6.5 percent.
} 
In addition to the value of imputed rent, housing wealth can also be accessed through a reverse mortgage and the proceeds used to support consumption in retirement. ${ }^{33}$ Whether the residual amount of housing wealth should be annuitized and included in monthly income when calculating replacement rates is more a policy issue. It is true that today's retirees tend to hold onto their home well into retirement. Most households (90 percent of couples and 62 percent of singles) enter retirement owning their own home (Venti and Wise 2001). In the absence of a precipitating event such as the death of a spouse or entry of a family member into a nursing home, most households continue to own their own home well into their eighties. Even when a shock occurs, selling the house is still a rare event; only 4 percent of households with a death and 11 percent of those with a nursing home entrant sell their house by the next wave of the HRS. In the absence of a shock, households that sell their house are likely to purchase another home and increase, rather than reduce, home equity. Thus, people do not appear interested in tapping their home equity for non-housing consumption. ${ }^{34}$

The fact that households do not currently tap home equity does not mean that policymakers should ignore the wherewithal that the elderly have to support themselves in retirement. Refusing to tap home equity may be a luxury that retirees and society can enjoy when the labor force is swelled with baby boomers and retirees are the relatively small number of depression-born babies. But as the baby boomers retire and the rate of growth of the labor force slows, the burden on workers of supporting increasing numbers of retirees will grow. It seems difficult in such an environment not to consider the residual value of housing equity as available for consumption. Therefore, on practical grounds, it may be desirable to include in the numerator of replacement rate calculations the annuitized residual value less any outstanding mortgage.

\section{Replacement Rates Including Imputed Rent}

\footnotetext{
${ }^{33}$ Equating the residual value with the amount that can be accessed through a reverse mortgage assumes that the home owner and financial institution both discount the rental stream at the same rate of interest, that all home owners live in their homes until death, and that the prices in the reverse mortgage market are not affected by moral hazard, adverse selection, or administrative costs.

${ }^{34}$ The results from the HRS and AHEAD closely correspond to findings from a 2000 AARP survey that revealed that more than 80 percent of respondents age 45 and over and more than 90 percent of those 65 and over would like to stay in their own home for as long as possible. Even if they should need help caring for themselves, 82 percent would prefer not to move from their current homes.
} 
Table 16 presents replacement rates as the definition of retirement income is expanded from Social Security alone to include pensions, financial assets, imputed rent, and finally the annuitized value of residual owner-occupied housing less mortgage debt. In the first case, pre-retirement income is defined in terms of AIME including earnings above the Social Security maximum, returns on financial assets, and imputed rent. In the second case, pre-retirement earnings is equal to the highest five of the last ten years prior to retirement indexed by prices to the year of retirement. The bottom line is that once imputed rent is added to the numerator and denominator, median replacement rates for couples and singles with pensions meet or exceed the 70-75 percent test of adequate replacement, depending on the definition of pre-retirement income. For those households without pensions, the median replacement rates fall below the adequacy threshold - the shortfall is modest when preretirement earnings are defined in terms of AIME and more substantial when defined as the best out of the last ten.

Finally, Table 17 shows the distribution of replacement rates by quintile, where preretirement income is defined comprehensively to include AIME plus earnings above the cap, returns on financial assets, and imputed rent. Quintiles are determined separately for married couples and for single-person households. The results show that regardless of quintile, households with pensions have more or less adequate levels of retirement income. Those without pensions generally do not. In both cases, the outcomes are less good when the denominator is income immediately prior to retirement.

\section{CONCLUSION}

First, the median replacement rate for newly retired worker beneficiaries according to both SSA and HRS is about 42 percent of AIME. The outcome is the net of two offsetting effects. On the one hand, real-world workers in the middle of the wage distribution have AIMEs that are less than 100 percent of the average wage index. This occurs because reat world workers do not have continuous earnings; they experience unemployment and disability and, in the case of women, drop out of the labor force to care for children. Interrupted careers produce lower AIMEs and higher replacement rates than SSA's policy model. Thus, if the lower earnings were the only factor at play, the median replacement rate for new beneficiaries would exceed that of the "medium earner." The countervailing factor 
is that workers retire before the normal retirement age and receive actuarially reduced benefits that lower replacement rates. In fact, based on actual retirement patterns, the replacement rate for the "medium earner" should be about 40 percent of AIME. So beneficiaries receive replacement rates slightly higher than the policy model would suggest because of lower earnings.

Second, men and women have very different earnings profiles. The median woman receives lower wages than her male counterpart, averages 13 years of zeros in her earnings history, and ends ups with an AIME well below that of the "medium earner." The median man, on the other hand, enjoys higher wages, has few years of zero earnings, and has an AIME (most likely coincidentally) virtually identical to that of the "medium earner." This earnings differential explains why the median replacement rate for a female worker is 52 percent and for a male worker 37 percent.

Third, the relationship between individual worker replacement rates and replacement rates received by households reveals two patterns. First, the median replacement rate for two-earner couples is significantly lower than that for the couple where the wife does not work (41 percent versus 58 percent). This outcome is virtually inevitable in a system that provides a 50-percent spouse's benefit. As women go to work, they increase the denominator with their AIME but often fail to increase the numerator. Second, the range of replacement rates is narrower for couples (62 percent to 32 percent) than for individual workers ( 72 percent to 30 percent). The high earned replacement rates for individuals disappear because they tend to belong to married women for whom the 50-percent spouse's benefit dominates the benefit based on their own earnings.

Fourth, the median Social Security replacement rate for those covered by an employer-sponsored pension is significantly lower for single-person households (40 percent versus 49 percent) and somewhat lower for couples ( 42 percent versus 48 percent) than for those households without pension coverage. The reason is that those with pension coverage have higher lifetime earnings. But adding payments from defined benefit plans and the annuitized value of defined contribution accumulations more than offsets the lower Social Security benefits, bringing the median replacement rate for those with pension coverage to 70 percent for couples and 76 percent for single individuals. Adding the annutized value of financial assets raises all replacement rates by another 10 percentage points. 
Fifth, the monthly value of imputed rent that will be consumed over the life of the household should be incorporated in the numerator of the replacement rate since it will be used to support consumption in retirement. For consistency, imputed rent should also be included in the denominator since the household was receiving imputed rent as part of its income before retirement. Making this adjustment produces replacement rates for those with pensions of 79 percent for couples and 89 percent for single person households. Those without pensions have replacement rates, using this comprehensive measure of income both before and after retirement, of 62 percent for couples and 63 percent for singles. These replacement rates drop about 15 percentage points, however, when recent earnings (the highest five years of the last ten) are used as the benchmark.

The ultimate message from this analysis is that the majority of households retiring today are in pretty good shape. Regardless of how retirement income and pre-retirement income are defined, households with pensions appear to meet the threshold of adequacy. Those without pensions do not fare as well, and some must be really struggling. But overall the picture is good. But today is in some sense the "golden age" of retirement income. Today's retirees are claiming Social Security benefits before the extension in the retirement age to 66 and then 67, which is equivalent to an across-the-board cut in benefits. Today's retirees also do not face the huge deductions in their Social Security check to cover Medicare premiums for Part B and Part D that tomorrow's retirees will. And today, the average retiree does not pay personal income tax on his Social Security benefits, whereas future retirees will increasingly see a portion of their benefits subject to taxation. Finally, most of today's retirees are covered primarily by a defined benefit plan and do not face the uncertainty associated with the inadequate lump-sum payments from 401(k) plans. The comfortable circumstances of today's retirees make it very hard to call attention to the challenges that future retirees will face. 


\section{REFERENCES}

AARP. 2000. "Fixing to Stay: A National Survey of Housing and Home Modification Issues."

Au, Andrew, Olivia S. Mitchell and John W. R. Phillips. 2004. "Modeling Lifetime Earnings Paths: Hypothetical versus Actual Workers.” Working Paper 2004-3. Boettner Center for Pensions and Retirement Research.

Banks, J., Blundell, R. and S. Tanner, S. (1998) "Is There a Retirement-Savings Puzzle?" American Economic Review 88:4 769-88.

Bernheim, B. Douglas. 1992. Is the Baby Boom Generation Preparing Adequately for Retirement? Technical Report. Merrill Lynch. Princeton N.J.

Bernheim, D., Skinner, J. and S. Weinberg (2001) "What Accounts for the Variation in Retirement Wealth among US Households?" American Economic Review 91:4, 83257

Boskin, Michael J. and John B. Shoven. 1984. "Concepts and Measurement of Earnings Replacement during Retirement.” NBER Working Paper No.1360. Cambridge, MA.: National Bureau of Economic Research.

Bosworth, Barry, Gary Burtless, and C. Eugene Steuerle. 1999. "Lifetime Earnings Patterns, the Distribution of Future Social Security Benefits, and the Impact of Pension Reform" CRR WP 1999-06. Chestnut Hill MA: Center for Retirement Research at Boston College.

Clingman, Michael and Orlo Nichols. 2004. "Scaled Factors for Hypothetical Earnings Examples under the 2004 Trustees Report Assumptions." Actuarial Note, 2004.3. Office of the Chief Actuary, Social Security Administration.

Congressional Budget Office. 1993. Baby Boomers in Retirement: An Early Perspective. September.

Crone, Theodore, Leonard Nakamura, and Richard Voith. 2004. "Hedonic Estimates of the Cost of Housing Services: Rental and Owner-Occupied," International Conference on Index Number Theory and the Measurement of Prices and Productivity. Vancouver, British Columbia.

Donkar, Eli N. 1981. "Average Wages for Indexing under the Social Security Act and the Automatic Determinations for 1979-81." Actuarial Note 103, Office of the Chief Actuary, Social Security Administration.

Engen, Eric, William Gale and Cori Uccello. 1999. "The Adequacy of Retirement Saving." Brookings Papers on Economic Activity. Number 2, pp. 65-165. 
Flavin, Marjorie and Takashi Yamashita. "Owner Occupied Housing and the Composition of the Household Portfolio over the Life Cycle.” NBER Working Paper No.6389. Cambridge, MA.: National Bureau of Economic Research.

Gustman, Alan and Thomas Steinmeier. 1999. "Effects of Pensions on Savings: Analysis with Data from the Health and Retirement Study." Carnegie-Rochester Conference Series on Public Policy. Vol. 50. June. P271-324.

Hurd, Michael and Susann Rohwedder .2003. "The Retirement Consumption Puzzle: Anticipated and Actual Declines in Spending at Retirement." NBER Working Paper No.9586. Cambridge, MA.: National Bureau of Economic Research.

Hurst, Erik. 2003.”Grasshoppers, Ants, and Pre-Retirement Wealth: A Test of Permanent Income." NBER Working Paper No.10098. Cambridge, MA.: National Bureau of Economic Research.

Juster, F. Thomas and Richard Suzman. 1995. "An Overview of the Health and Retirement Study." Journal of Human Resources, Vol. 30, Supplement, pp. S7-S56.

Moore, James F. and Olivia S. Mitchell. 1997. "Projected Retirement Wealth and Savings Adequacy in the Health and Retirement Study." NBER Working Paper No. 6240. Cambridge, MA.: National Bureau of Economic Research.

Palmer, Bruce A.. 2001. “2001 GSU/AON RETIRE Project Report.” Research Report Series No. 01-1 (June).

Scholz, John Karl, Ananth Seshadri, and Surachai Khitatrakun, "Are Americans Saving 'Optimally' for Retirement?” NBER Working Paper 10260. Cambridge, MA.: National Bureau of Economic Research.

Sheiner, Louise and David Weil. 1993. "The Housing Wealth of the Aged." NBER Working Paper No. 4115. Cambridge, MA.: National Bureau of Economic Research.

Social Security Administration. 2004. Performance and Accountability Report, Fiscal Year 2004.

Steuerle, Eugene, Christopher Spiro, and Adam Carasso. 2000. "Do Analysts Use Atypical Workers to Evaluate Social Security?" Straight Talk on Social Security and Retirement Policy, No. 19 (March 15).

U.S. Bureau of the Census. 2005. Annual Statistical Supplement: 2004-2005. http://www.census.gov/prod/www/statistical-abstract-04.html

Venti, Steven F., and David A. Wise. 2001. "Aging and Housing Equity: Another Look." NBER Working Paper 8608. Cambridge, MA.: National Bureau of Economic Research. 
Table 1. Percent of Pre-Retirement Salary Required to Maintain Living Standards

\begin{tabular}{|l|c|c|}
\hline $\begin{array}{l}\text { Pre- } \\
\text { retirement } \\
\text { earnings }\end{array}$ & Couples & $\begin{array}{l}\text { Single } \\
\text { workers }\end{array}$ \\
\hline$\$ 20,000$ & 83 & 78 \\
\hline$\$ 50,000$ & 76 & 74 \\
\hline$\$ 90,000$ & 75 & 82 \\
\hline
\end{tabular}

Source: Bruce A. Palmer. 2001. “2001 GSU/AON RETIRE Project Report.” Research Report Series No. 01-1 (June).

Table 2. Social Security Replacement Rates for Hypothetical Workers, 2004

\begin{tabular}{|l|c|c|c|c|}
\hline \multirow{2}{*}{ Earner } & \multicolumn{2}{|c|}{$\begin{array}{c}\text { Replacement Rate as a percent } \\
\text { of Career Average Earnings }\end{array}$} & $\begin{array}{c}\text { Replacement Rate as a percent } \\
\text { of AIME }\end{array}$ \\
\cline { 2 - 5 } & Age 62 & Age 65 & Age 62 & Age 65 \\
\hline Scaled Low Earner & 45.2 & 56.5 & 46.1 & 62.7 \\
\hline Scaled Medium Earner & 33.5 & 41.9 & 34.1 & 46.5 \\
\hline Scaled High Earner & 28.2 & 35.2 & 28.7 & 39.0 \\
\hline Steady Maximum Earner & 23.8 & 29.8 & 24.7 & 32.3 \\
\hline
\end{tabular}

Source: 2004 Trustees Report, Table VI.F11 and author's calculations.

Table 3. Percent Distribution of Initial Social Security Benefit Awards, 2003

\begin{tabular}{|l|r|r|}
\hline \multicolumn{1}{|c|}{ Age } & Women & \multicolumn{1}{c|}{ Men } \\
\hline 62 & 58.6 & 53.3 \\
\hline 63 & 7.3 & 7.9 \\
\hline 64 & 11.6 & 13.1 \\
\hline 65 & 16.5 & 22.4 \\
\hline $66-69$ & 3.0 & 2.3 \\
\hline 70 and over & 2.9 & 1.0 \\
\hline Total & 100.0 & 100.0 \\
\hline
\end{tabular}

Source: Social Security Bulletin, Annual Statistical Supplement 2002. Table 6.B5 and authors' calculations.

Table 4. Percentage with PIA Amounts below Hypothetical Earners for Those Retiring in 2003.

\begin{tabular}{|l|c|c|c|c|}
\hline Earner & All Males & All Females & All Workers & $\begin{array}{l}\text { Females, not } \\
\text { dually entitled }\end{array}$ \\
\hline Scaled Low & 13.2 & 44.0 & 27.5 & 31.0 \\
\hline Scaled Medium & 37.3 & 82.7 & 58.5 & 78.2 \\
\hline Scaled High & 74.1 & 97.5 & 85.3 & 96.9 \\
\hline
\end{tabular}

Source: Clingman and Nichols (2004) 
Table 5. Average Number of Years with Zero Earnings ${ }^{a}$ of New Retired-Worker Beneficiaries

\begin{tabular}{|c|c|c|c|c|c|c|}
\hline \multirow{2}{*}{ Year } & \multicolumn{2}{|c|}{ Total } & \multicolumn{2}{c|}{ Men } & \multicolumn{2}{c|}{ Women } \\
\cline { 2 - 7 } & SSA $^{\mathrm{b}}$ & HRS & SSA $^{\mathrm{b}}$ & HRS & SSA $^{\mathrm{b}}$ & HRS \\
\hline Before 1999 & & 9.5 & & 5.8 & & 13.6 \\
\hline 1999 & 9.5 & 9.8 & 6.1 & 6.2 & 13.7 & 13.4 \\
\hline 2000 & 9.2 & 9.4 & 6.2 & 5.7 & 13.8 & 13.8 \\
\hline 2001 & 9.4 & 8.5 & 6.0 & 5.0 & 13.5 & 12.7 \\
\hline 2002 & 9.1 & 8.7 & 5.9 & 5.5 & 12.9 & 12.7 \\
\hline
\end{tabular}

Source: Authors' calculations from the HRS and Social Security Administration. 2004. Performance and Accountability Report, FY 2004, pp125.

a. Years of zero earnings shown are measured from age 22 to the last year before first collecting retired-worker benefits. This calculation does not subtract out the lowest 5 years as is done in the benefit calculation.

b. Based on the $1 \%$ Continuous Work History Sample supplemented with information from the Master Earnings File for persons retiring in 1999-2003.

Table 6. Median Social Security Replacement Rates ${ }^{a}$ of New Retired-Worker Beneficiaries

\begin{tabular}{|c|c|c|c|c|c|c|}
\hline \multirow{2}{*}{ Year } & \multicolumn{2}{|c|}{ Total } & \multicolumn{2}{c|}{ Men } & \multicolumn{2}{c|}{ Women } \\
\cline { 2 - 7 } & SSA $^{\mathrm{b}}$ & HRS & SSA $^{\mathrm{b}}$ & HRS & SSA $^{\mathrm{b}}$ & HRS \\
\hline Before 1999 & & 42.4 & & 35.9 & & 52.3 \\
\hline 1999 & 42.8 & 44.1 & 37.0 & 37.6 & 52.0 & 50.6 \\
\hline 2000 & 42.9 & 43.0 & 37.5 & 37.2 & 52.4 & 52.0 \\
\hline 2001 & 42.6 & 42.0 & 36.7 & 36.6 & 51.8 & 52.1 \\
\hline 2002 & 42.1 & 40.6 & 36.5 & 35.5 & 50.8 & 49.7 \\
\hline
\end{tabular}

Source: Authors' calculations from the HRS and Social Security Administration. 2004. Performance and Accountability Report, FY 2004, pp125.

a. The replacement rate is calculated as the ratio of the retired worker's benefit based on his or her own earnings to his or her average indexed monthly earnings (AIME). The AIME is the worker's highest 35 years of earnings, which have been adjusted for changes in the average wage index to the year of attainment of age. b. Based on the 1\% Continuous Work History Sample supplemented with information from the Master Earnings File for persons retiring in 1999-2003. 
Table 7. Median Replacement Rates ${ }^{a}$ of New Retired-Worker Beneficiaries, by AIME Quintile

\begin{tabular}{|c|c|c|c|c|c|c|}
\hline \multirow{2}{*}{ Year } & \multirow{2}{*}{ Source } & \multicolumn{5}{|c|}{ AIME Quintile } \\
\cline { 3 - 7 } & & Lowest & Second & Third & Fourth & Highest \\
\hline 1999 & SSA & 72.5 & 51.6 & 41.5 & 35.9 & 31.2 \\
\hline & HRS & 72.0 & 50.6 & 41.8 & 36.2 & 31.9 \\
\hline & & & & & & \\
\hline 2000 & SSA & 71.6 & 52.2 & 41.5 & 36.8 & 31.5 \\
\hline & HRS & 72.0 & 49.6 & 40.1 & 35.4 & 30.1 \\
\hline & & & & & & \\
\hline 2001 & SSA & 70.9 & 50.8 & 40.5 & 35.0 & 30.2 \\
\hline & HRS & 72.0 & 48.9 & 39.9 & 35.4 & 30.5 \\
\hline & & & & & & \\
\hline 2002 & SSA & 70.1 & 50.8 & 40.5 & 35.0 & 30.2 \\
\hline & HRS & 68.9 & 47.9 & 39.1 & 34.3 & 29.1 \\
\hline
\end{tabular}

Source: Authors' calculations from the HRS and Social Security Administration. 2004. Performance and Accountability Report, FY 2004, pp128.

a. The replacement rate is calculated as the ratio of the retired worker's benefit based on his or her own earnings to his or her average indexed monthly earnings (AIME). The AIME is the worker's highest 35 years of earnings, which have been adjusted for changes in the average wage index to the year of attainment of age 62 .

b. Based on the $1 \%$ Continuous Work History Sample supplemented with information from the Master Earnings File for persons retiring in 1999-2003. 
Table 8. Median Social Security Replacement Rates for HRS Households

\begin{tabular}{|c|c|c|r|}
\hline Household type & \multicolumn{2}{|c|}{ Replacement rate } & \multirow{2}{*}{$\begin{array}{c}\text { Number of } \\
\text { HRS } \\
\text { observations }\end{array}$} \\
\cline { 2 - 3 } & $\begin{array}{c}\text { Predicted } \\
\text { from SSA } \\
\text { study }\end{array}$ & HRS & 2,581 \\
\hline Couples & 44.6 & 44.1 & 598 \\
\hline Spouse AIME =0 & 55.5 & 58.0 & 1,983 \\
\hline Spouse AIME>0 & 41.5 & 41.1 & 1,336 \\
\hline Single & 47.3 & 45.2 & 385 \\
\hline Men & 37.0 & 38.7 & 941 \\
\hline Women & 52.0 & 48.7 & 3,917 \\
\hline All & 45.5 & 44.4 & 97.4 \\
\hline
\end{tabular}

Source: Authors' predictions based on results of SSA's Performance and Accountability Report (2004) and calculations from the HRS.

Table 9. Distribution of Couples by Ratio of Secondary Earner's AIME to Primary Earner's AIME

\begin{tabular}{|l|c|}
\hline $\begin{array}{l}\text { Ratio of Secondary Earner's AIME to } \\
\text { Primary Earner's AIME }\end{array}$ & Percentage of Couples \\
\hline $0-0.20$ & 20.8 \\
\hline $0.20-0.40$ & 26.4 \\
\hline $0.40-0.60$ & 22.1 \\
\hline $0.60-0.80$ & 17.4 \\
\hline 0.80 or more & 13.3 \\
\hline
\end{tabular}

Source: Authors' estimates from the HRS.

Note: This table excludes the 23 percent of couples where the second earner has a zero AIME.

Table 10. Median Social Security Replacement Rates for HRS Households, by Quintiles of Household AIME

\begin{tabular}{|l|c|c|}
\hline AIME Quintile & Singles & Couples \\
\hline Lowest & 72.0 & 62.7 \\
\hline Second & 51.0 & 48.6 \\
\hline Third & 42.2 & 43.8 \\
\hline Fourth & 36.9 & 39.1 \\
\hline Highest & 32.3 & 33.4 \\
\hline All & 42.2 & 43.8 \\
\hline
\end{tabular}

Source: Authors' calculations from the HRS. 
Table 11. Replacement Rate Recipients by Marital Status and Gender

\begin{tabular}{|l|c|c|c|c|}
\hline $\begin{array}{c}\text { Replacement } \\
\text { rate }\end{array}$ & \multicolumn{2}{|c|}{ Single } & \multicolumn{2}{c|}{ Married } \\
\hline & Men & Women & Men & Women \\
\hline$>0.75$ & 6.4 & 27.5 & 12.1 & 54.0 \\
\hline $0.60-0.75$ & 4.1 & 20.1 & 12.4 & 63.4 \\
\hline $0.45-0.60$ & 7.9 & 21.2 & 30.0 & 40.8 \\
\hline $0.30-0.45$ & 9.4 & 11.4 & 57.6 & 21.6 \\
\hline$<0.30$ & 9.2 & 4.3 & 82.7 & 3.8 \\
\hline
\end{tabular}

Source: Authors' calculations from the HRS. 
Table 12. Median Replacement Rates for Couples and Single Individuals by Type of Coverage

\begin{tabular}{|c|c|c|c|c|}
\hline \multirow[b]{2}{*}{ Replacement income source } & \multicolumn{2}{|c|}{ Couples } & \multicolumn{2}{|c|}{ Single individuals } \\
\hline & $\begin{array}{l}\text { Without } \\
\text { pensions }\end{array}$ & $\begin{array}{c}\text { With } \\
\text { pensions }\end{array}$ & $\begin{array}{l}\text { Without } \\
\text { pensions }\end{array}$ & $\begin{array}{c}\text { With } \\
\text { pensions }\end{array}$ \\
\hline \multicolumn{5}{|c|}{ Denominator $=$ AIME } \\
\hline Social Security & 47.9 & 42.3 & 49.1 & 40.1 \\
\hline Social Security + pensions ${ }^{\mathrm{a}}$ & 47.9 & 70.0 & 49.1 & 76.4 \\
\hline $\begin{array}{l}\text { Social Security + } \text { pensions }^{\mathrm{a}}+ \\
\text { financial assets }\end{array}$ & 60.0 & 81.5 & 59.4 & 89.6 \\
\hline \multicolumn{5}{|c|}{ Denominator $=$ AIME plus earnings above the cap + Returns on Financial Assets } \\
\hline Social Security & 43.0 & 37.7 & 46.2 & 38.0 \\
\hline Social Security + pensions ${ }^{\mathrm{a}}$ & 43.0 & 63.3 & 46.2 & 70.4 \\
\hline $\begin{array}{l}\text { Social Security }+ \text { pensions }^{\mathrm{a}}+ \\
\text { financial assets }\end{array}$ & 55.3 & 73.8 & 57.6 & 86.3 \\
\hline \multicolumn{5}{|c|}{$\begin{array}{c}\text { Denominator }=\text { CPI Indexed-Top } 5 \text { Household Pre-Retirement Earnings }+ \text { Returns on Financial } \\
\text { Assets }\end{array}$} \\
\hline Social Security & 34.4 & 29.5 & 32.8 & 27.8 \\
\hline Social Security + pensions ${ }^{\mathrm{a}}$ & 34.4 & 51.5 & 32.8 & 55.7 \\
\hline $\begin{array}{l}\text { Social Security + pensions }{ }^{\mathrm{a}}+ \\
\text { financial assets }^{\mathrm{b}}\end{array}$ & 45.4 & 60.1 & 44.4 & 66.9 \\
\hline Addendum: & & & & \\
\hline Percent of retiring population $^{c}$ & 25 & 55 & 11 & 9 \\
\hline
\end{tabular}

Source: Authors' calculations from the HRS.

a. For those with pension coverage, IRA assets are included in defined contribution wealth; for those without pension coverage IRA assets are classified as part of financial assets.

b. Financial as sets are annuitized using a factor of 13.86 for households; 11.27 for single men; and 12.45 percent for single women.

c. In the case of couples, the 55 percent consists of 15 percent of retirees with a defined contribution plan only, 24 percent with a defined benefit plan only, and 16 percent with both. The 9 percent of retirees who are single and covered by a pension consists of 3 percent with a defined contribution plan only, 4.5 percent with a defined benefit plan only, and 1.5 percent with both. 


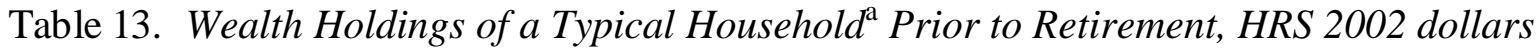

\begin{tabular}{lrc}
\hline Source & Amount & Percent of total \\
\hline & & \\
Primary house & $\$ 81,398$ & 16.7 \\
Business assets & 4,092 & 0.8 \\
Financial assets & 29,451 & 6.0 \\
Defined contribution $^{\mathrm{b}}$ & 30,222 & 6.2 \\
Defined benefit $_{\text {Social Security }}$ & 88,180 & 18.0 \\
Other Non-financial assets & 234,636 & 48.0 \\
Total & 20,730 & 4.2 \\
\hline
\end{tabular}

Source: Authors' calculations based on the HRS

a. The "typical" household refers to the mean of the middle 20 percent of the sample.

b. IRA assets are included in defined contribution wealth.

Table 14. Rent as a Percent of Total House Value

\begin{tabular}{|c|c|c|c|}
\hline \multirow{2}{*}{ Discount Rate } & \multicolumn{3}{|c|}{ Appreciation Rate } \\
\cline { 2 - 4 } & 0.5 percent & 1.0 percent & 1.5 percent \\
\hline 3 percent & 2.49 & 1.98 & 1.48 \\
\hline 5 percent & 4.48 & 3.96 & 3.45 \\
\hline 6 percent & 5.47 & 4.95 & 4.43 \\
\hline 7 percent & 6.47 & 5.94 & 5.42 \\
\hline 9 percent & 8.46 & 7.92 & 7.39 \\
\hline
\end{tabular}

Source: Authors' estimates.

Table 15. Present Discounted Value of Imputed Rent as a Percent of Total House Value

\begin{tabular}{|c|c|c|c|}
\hline \multirow{2}{*}{ Discount Rate } & \multicolumn{3}{|c|}{ Appreciation Rate } \\
\cline { 2 - 4 } & 0.5 percent & 1.0 percent & 1.5 percent \\
\hline 3 percent & 45.3 & 38.3 & 30.3 \\
\hline 5 percent & 65.9 & 61.5 & 56.6 \\
\hline 6 percent & 73.0 & 69.5 & 65.6 \\
\hline 7 percent & 78.6 & 75.8 & 72.7 \\
\hline 9 percent & 86.4 & 84.7 & 82.7 \\
\hline
\end{tabular}

Source: Authors' estimates. 
Table 16. Median Replacement Rates Including Housing for Couples and Singles by Pension Coverage

\begin{tabular}{|l|c|l|l|l|}
\hline \multirow{2}{*}{ Replacement income source } & \multicolumn{2}{|c|}{ Couples } & \multicolumn{2}{|c|}{ Singles } \\
\cline { 2 - 4 } & $\begin{array}{c}\text { Without } \\
\text { pensions }\end{array}$ & With pensions & $\begin{array}{c}\text { Without } \\
\text { pensions }\end{array}$ & With pensions \\
\hline
\end{tabular}

Denominator $=$ AIME plus earnings above the cap + Returns on Financial Assets + Imputed Rent

\begin{tabular}{|c|c|c|c|c|}
\hline Social Security & 38.7 & 34.0 & 39.8 & 32.2 \\
\hline Social Security + Pensions ${ }^{b}$ & 38.7 & 57.8 & 39.8 & 62.8 \\
\hline $\begin{array}{l}\text { Social Security +Pensions }{ }^{b}+ \\
\text { Financial Assets }^{\mathrm{c}}\end{array}$ & 48.9 & 66.8 & 48.8 & 71.4 \\
\hline $\begin{array}{l}\text { Social Security }+ \text { Pensions }{ }^{\mathrm{b}}+ \\
\text { Financial Assets }+ \text { Imputed Rent }\end{array}$ & 60.2 & 76.2 & 62.2 & 87.9 \\
\hline $\begin{array}{l}\text { Social Security }+ \text { Pensions }^{\mathrm{b}}+ \\
\text { Financial Assets }^{\mathrm{c}}+\text { Imputed Rent }+ \\
\text { Residual Housing Wealth }\end{array}$ & 62.3 & 78.5 & 63.3 & 89.3 \\
\hline \multicolumn{5}{|c|}{$\begin{array}{c}\text { Denominator }=\text { CPI Indexed-Top } 5 \text { Household Pre-Retirement Earnings }+ \text { Returns on Financial Asse } \\
\qquad+ \text { Imputed Rent }\end{array}$} \\
\hline Social Security & 31.6 & 27.0 & 30.1 & 29.4 \\
\hline Social Security + Pensions & 31.6 & 47.6 & 30.1 & 49.9 \\
\hline $\begin{array}{l}\text { Social Security +Pensions }{ }^{\mathrm{b}}+ \\
\text { Financial Assets }^{\mathrm{c}}\end{array}$ & 41.8 & 55.2 & 39.1 & 59.1 \\
\hline $\begin{array}{l}\text { Social Security }+ \text { Pensions }{ }^{\mathrm{b}}+ \\
\text { Financial Assets }+ \text { Imputed Rent }\end{array}$ & 50.2 & 63.1 & 50.8 & 70.0 \\
\hline $\begin{array}{l}\text { Social Security }+ \text { Pensions }^{\mathrm{b}}+ \\
\text { Financial Assets }{ }^{\mathrm{c}}+\text { Imputed Rent }++ \\
\text { Residual Housing Wealth }\end{array}$ & 52.1 & 64.9 & 52.8 & 72.1 \\
\hline $\begin{array}{l}\text { Addendum: } \\
\text { Percent of retiring population }\end{array}$ & 25 & 55 & 11 & 9 \\
\hline
\end{tabular}

Source: Authors' calculations based on the HRS.

a. Assets are annuitized using a factor of 13.86 for households; 11.27 for single men; and 12.45 percent for single women.

b. For those with pension coverage, IRA assets are included in defined contribution wealth; for those without pension coverage IRA assets are classified as part of financial assets.

c. The real return on financial assets is assumed to be 2.6 percent. 
Table 17. Replacement Rates by Quintile of Household AIME, by Couples and Singles

\begin{tabular}{|c|c|c|c|c|}
\hline \multirow[b]{2}{*}{ Quintile } & \multicolumn{2}{|c|}{ Couples } & \multicolumn{2}{|c|}{ Singles } \\
\hline & $\begin{array}{l}\text { Without } \\
\text { pensions }\end{array}$ & With pensions & $\begin{array}{l}\text { Without } \\
\text { pensions }\end{array}$ & With pensions \\
\hline $\begin{array}{l}\text { Numerator: Social Security } \\
\text { +Pensions }{ }^{\mathrm{a}}+\text { Financial } \\
\text { Assets }{ }^{\mathrm{b}}+\text { Imputed Rent }\end{array}$ & \multicolumn{4}{|c|}{$\begin{aligned} \text { Denominator }= & \text { AIME plus earnings above the cap + Returns on } \\
& \text { Financial Assets }+ \text { Imputed Rent }\end{aligned}$} \\
\hline Lowest & 73.3 & 146.9 & 79.2 & 191.3 \\
\hline Second & 56.1 & 75.1 & 69.3 & 125.2 \\
\hline Third & 60.1 & 73.1 & 51.6 & 73.1 \\
\hline Fourth & 51.4 & 68.0 & 46.9 & 76.4 \\
\hline Highest & 50.6 & 72.4 & 49.1 & 86.4 \\
\hline $\begin{array}{l}\text { Numerator: Social Security } \\
\text { +Pensions }{ }^{\mathrm{a}}+\text { Financial } \\
\text { Assets }^{\mathrm{b}}+\text { Imputed Rent }\end{array}$ & \multicolumn{4}{|c|}{$\begin{array}{l}\text { Denominator = CPI Indexed-Top } 5 \text { Household Pre-Retirement } \\
\text { Earnings }+ \text { Returns on Financial Assets }{ }^{\mathrm{c}}+\text { Imputed Rent }\end{array}$} \\
\hline $\begin{array}{l}\text { Lowest } \\
\end{array}$ & 56.1 & 93.0 & 55.0 & 102.6 \\
\hline Second & 53.4 & 68.0 & 56.8 & 68.7 \\
\hline Third & 48.7 & 61.0 & 47.9 & 58.1 \\
\hline Fourth & 43.6 & 55.6 & 46.9 & 67.6 \\
\hline Highest & 41.9 & 60.0 & 50.7 & 76.4 \\
\hline $\begin{array}{l}\text { Addendum: } \\
\text { Percent of retiring } \\
\text { population }\end{array}$ & 25 & 55 & 11 & 9 \\
\hline
\end{tabular}

Source: Authors' calculations based on the HRS.

a. For those with pension coverage, IRA assets are included in defined contribution wealth; for those without pension coverage IRA assets are classified as part of financial assets.

b. Assets are annuitized using a factor of 13.86 for households; 11.27 for single men; and 12.45 percent for single women.

c. The real return on financial assets is assumed to be 2.6 percent. 
Figure 1. Mean Wage \& Salary Income and Average Wage Index, 1951-2003.

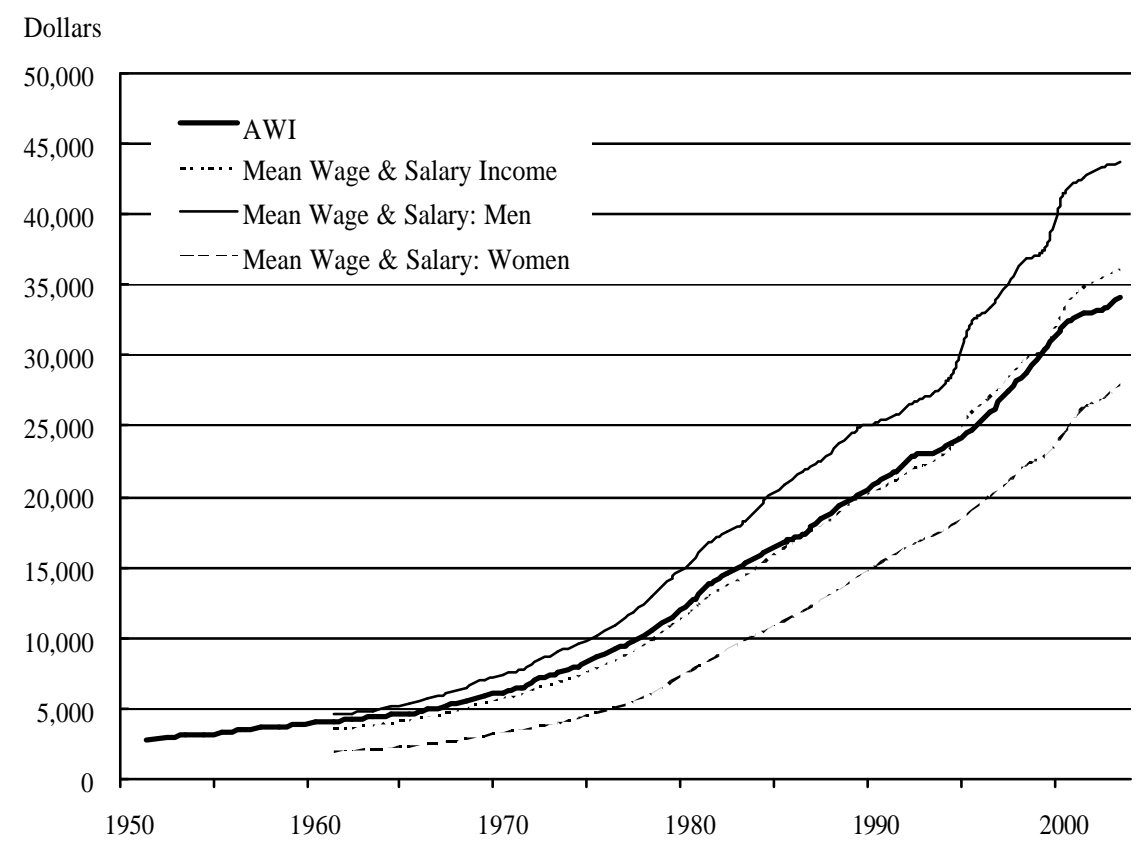

Source: Authors' calculations based on Current Population Survey (various years); Social Security Administration (2005), http://www.ssa.gov/OACT/COLA/awiseries.html . 
Figure 2a. Steady Earnings Profile, 1936 Birth Year, 2003 Dollars.

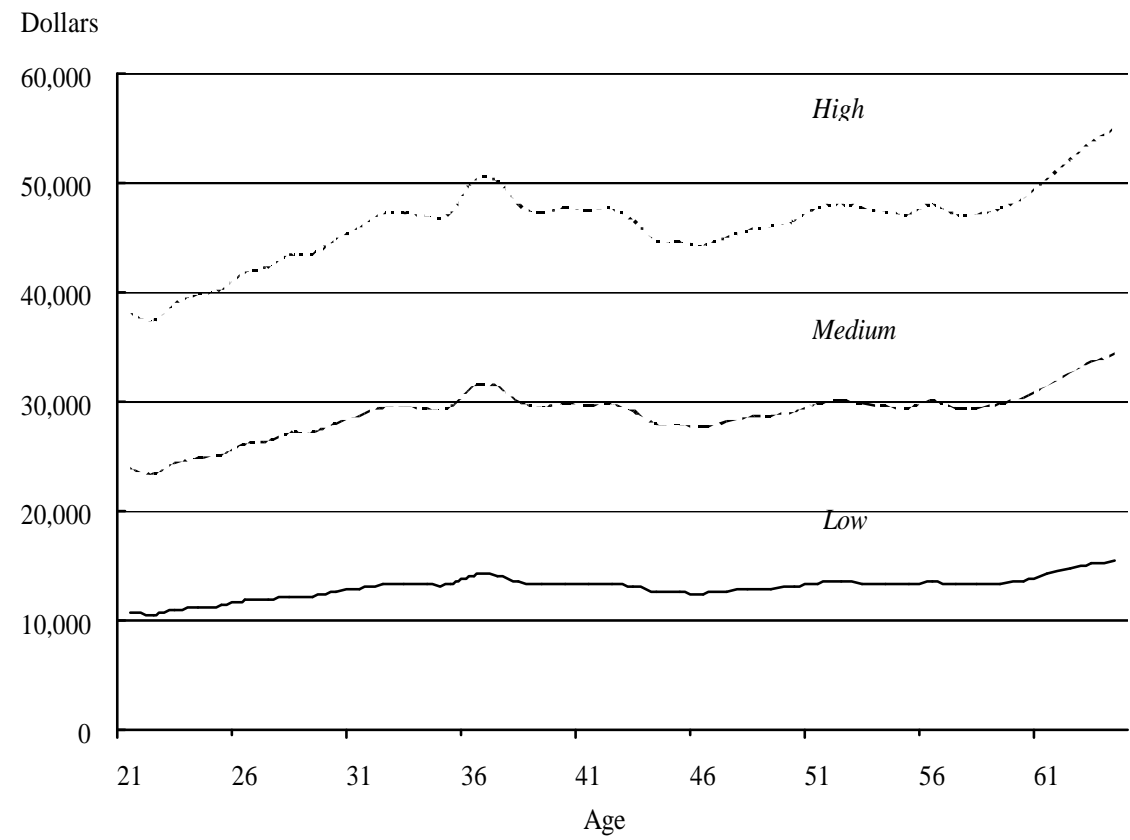

Figure 2b. Scaled Earnings Profile, 1936 Birth Year, 2003 Dollars.

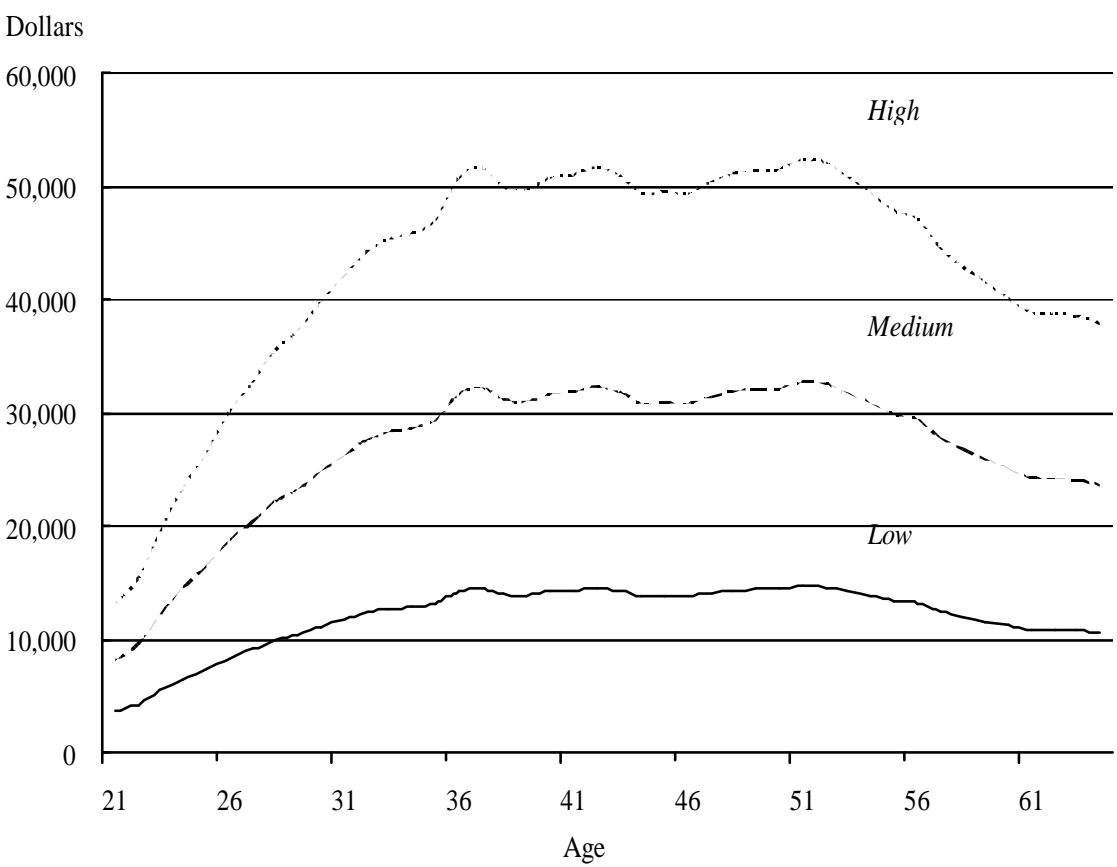

Authors' calculations based on Clingman and Nichols (2004); Social Security Administration (2005), http://www.ssa.gov/OACT/COLA/awiseries.html. 
Figure 3. Median 10 Percent of Earnings of 1936 Cohort and SSA's Scaled Medium Earnings, 1992 Dollars.

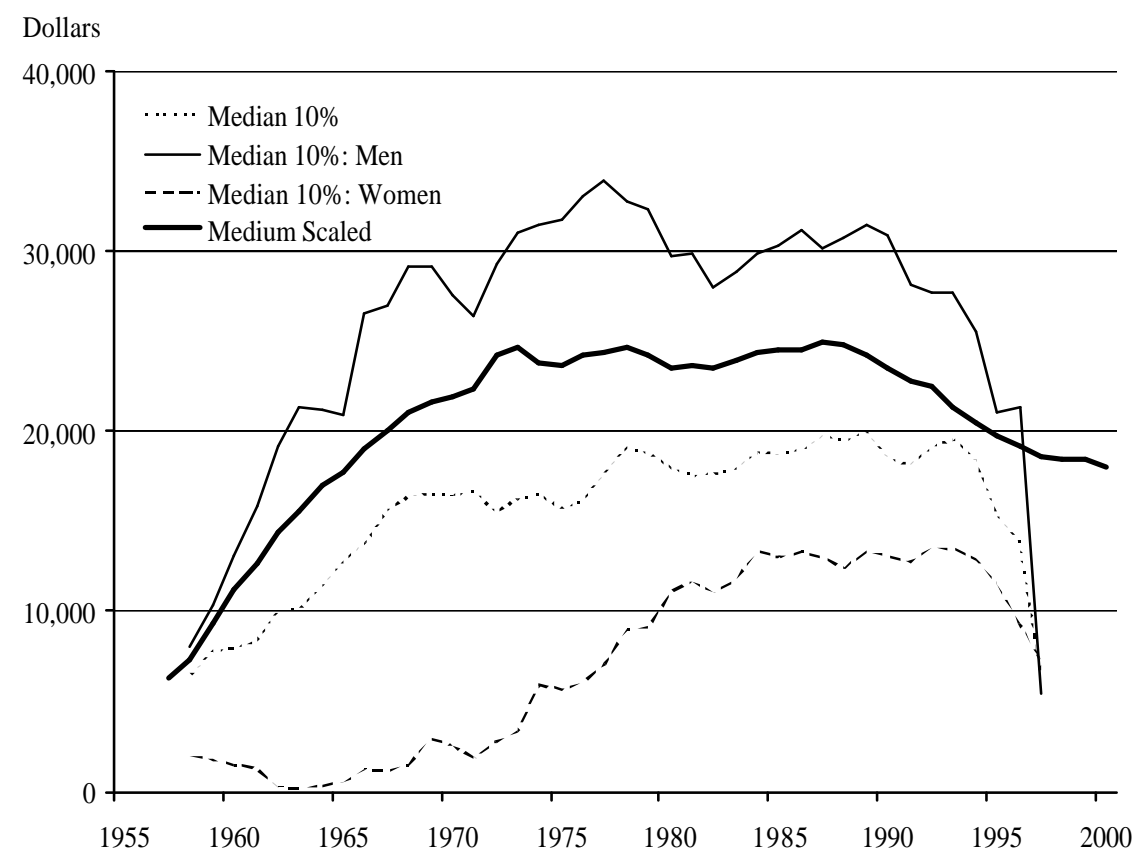

Source: Authors' calculations from the HRS (various years), based on presentation in Au et. all (2001). 
Figure 4. Median Wage \& Salary Income and Average Wage Index, 1951-2003

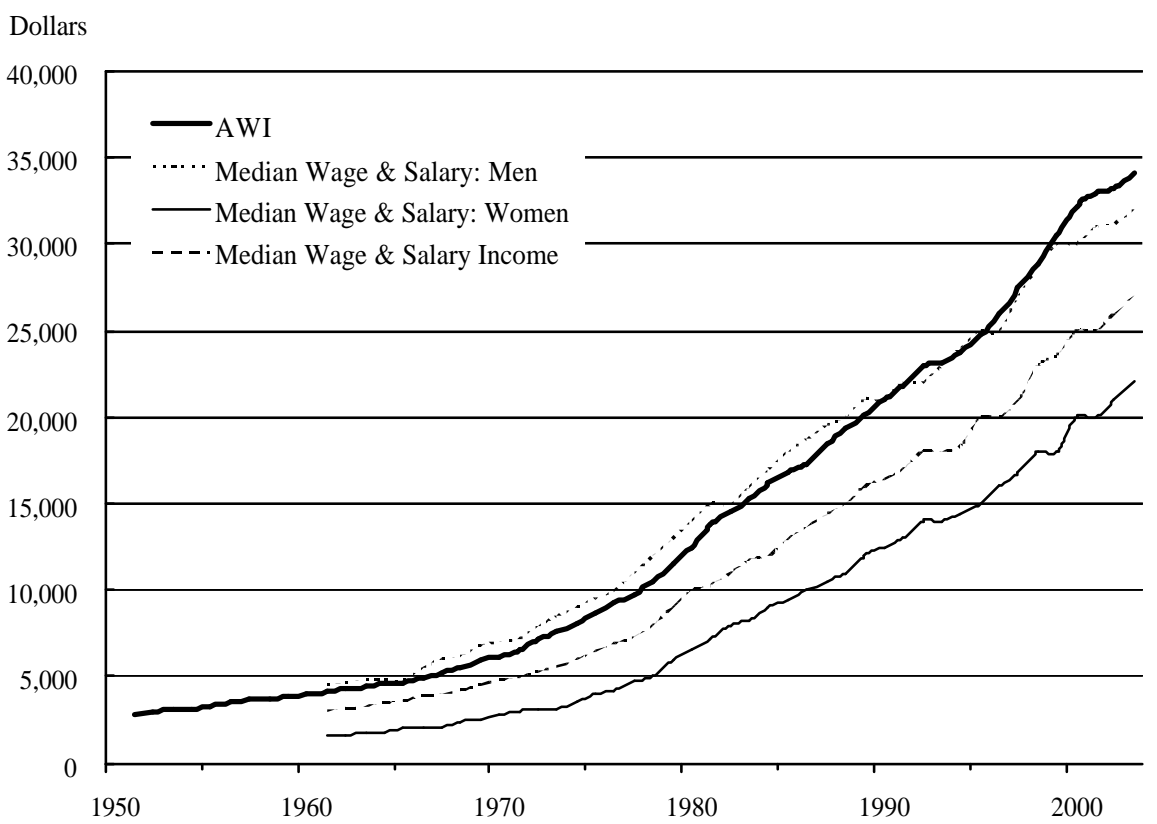

Source: Authors' calculations based on Current Population Survey (various years); Social Security Administration (2005), http://www.ssa.gov/OACT/COLA/awiseries.html .

Figure 5. Income Shares by Gender, 1962-2003.

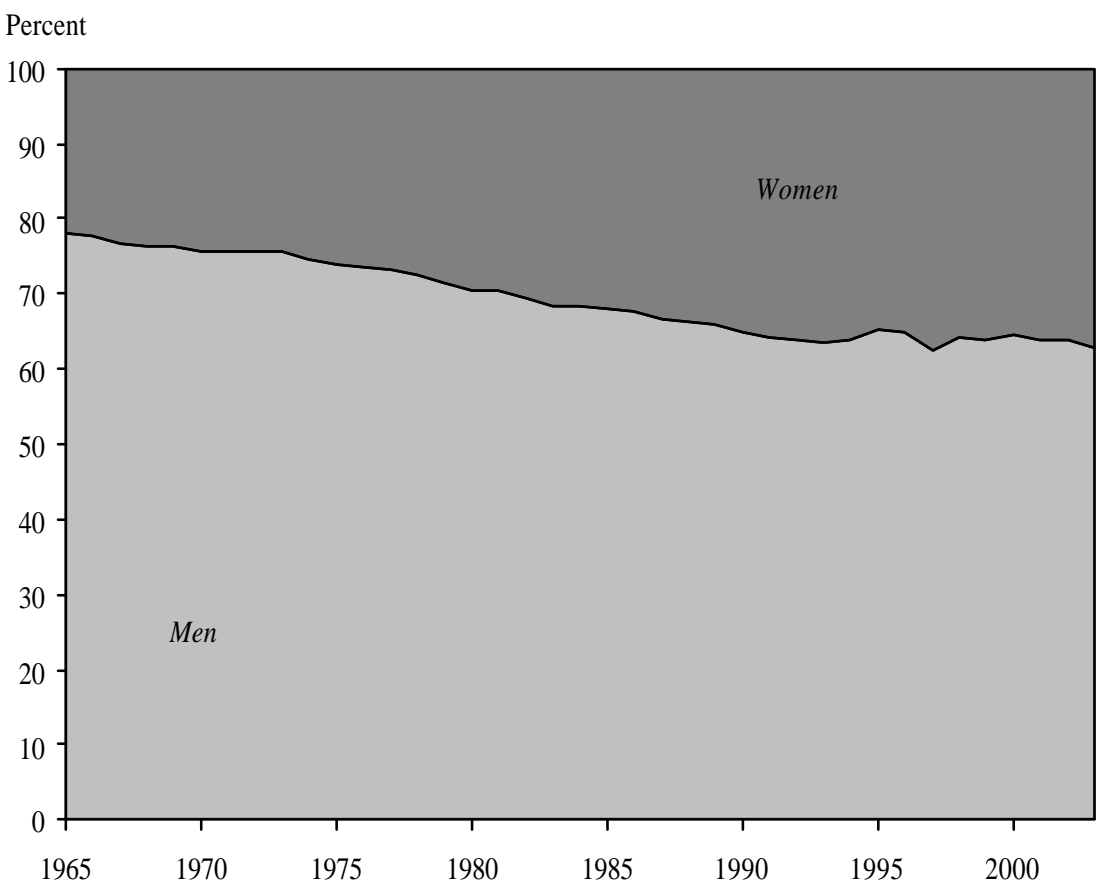

Source: Authors' calculations based on Current Population Survey (various years). 
Figure 6. Space Rent as a Percent of Housing Stock, 1945-2003

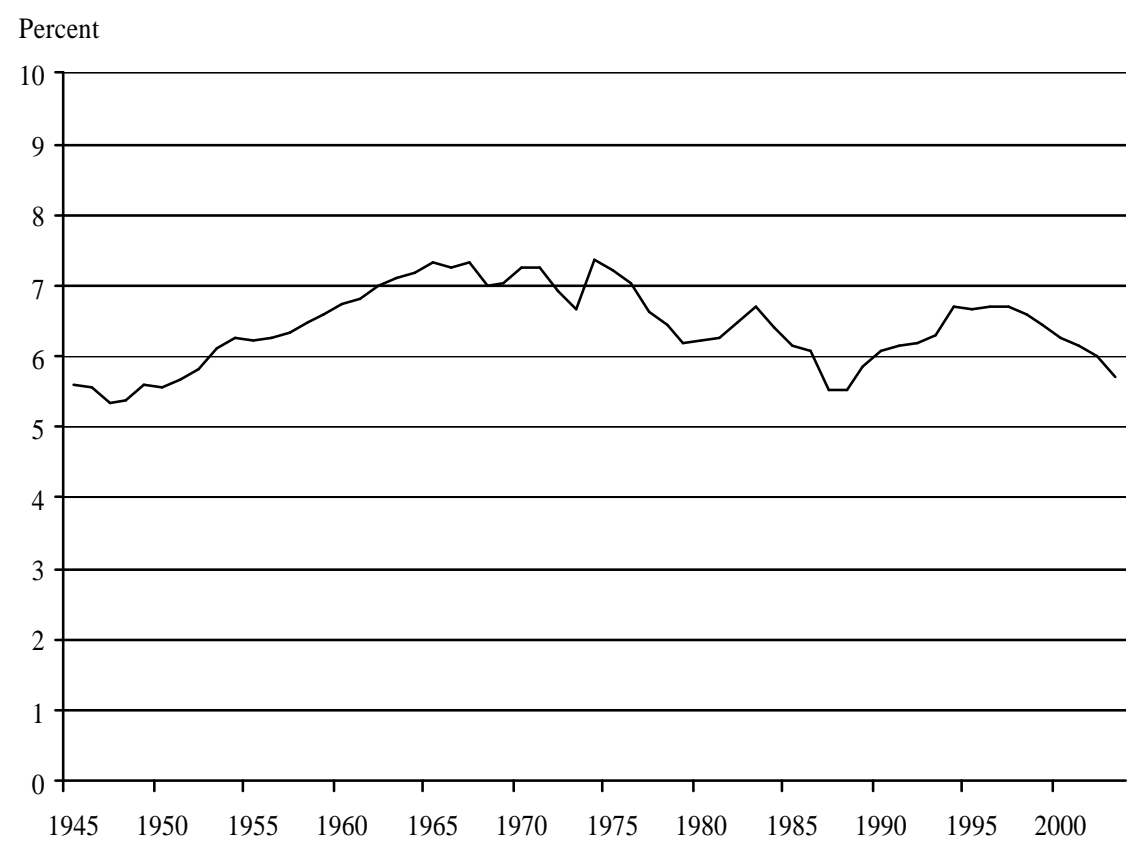

Source: Authors' calculations based on the Board of Governors, Flow of Funds Accounts (various years) and the Bureau of Economic Analysis, National Income and Product Accounts (various years). 
Appendix A: DESCRIPTION OF HRS DATA USED IN THE ANALYSIS

\section{DERIVATION OF INDIVIDUAL SAMPLE}

HRS-1992-RAND Sample

—unmatched individuals

SAMPLE SIZE
13,276

3,807

9,469

-Weights $<0$

116

These are individuals who married HRS

wave 1 respondents after wave 1 , not to be used in wave 1 analysis.

SAMPLE SIZE

9,353

—Earnings missing before age 61

518

The HRS restricted SS earnings data are used up to 1991. Earnings after that are from self-reported data. Imputations 1) If earnings are missing, put zeros if individuals report no work; 2) if missing in one year, but greater than zero in the adjacent years, use the average of adjacent years; 3) Zeros if last year reported working is less than the missing year. 4) Assign-10 if we don't observe the individual anymore (death, drop out of sample), 5) Impute earnings for ages 62,63 and 64, taking age 61 earnings and keeping a constant dollar earnings.

\section{SAMPLE SIZE}

\section{8,835}

-Missing retirement age

\section{2,045 (These are IMPUTED)}

For retirement age, RAND data include a variable for the year individuals first receive Social Security (rassageb). Imputations: 1) from rassageb there are about 3,197/8,835 missing values. For these individuals, we use the RAND retirement year indicator ( $r$ *retyr) to impute their retirement age. 2) Many have rassageb values less than 62, which would indicate disability. To correct some of these, radiget codes 0 if individuals never received SSI or disability benefits. For those with radiget $==0$ and rassageb $<62$, retirement age is increased to 62.

-Imputation.

For those with missing retirement age, we impute the retirement age by randomly assign a retirement age following Social Security age of first receipt of benefits, using the different probabilities available for males and females. (See Table 2).

\section{SAMPLE SIZE}

\section{8,835}

—Retirement age $<62$

894

These are individuals that, after al the imputations have been done, still have retirement age less than 62 , and we can not say that they are not receiving disability.

\section{INDIVIDUAL DATA SAMPLE SIZE $\quad \mathbf{7 , 9 4 1}$}




\section{DERIVATION OF HOUSEHOLD SAMPLE}

In this sample, 1,064 individuals do not have 40 or more quarters of SS participation, and 1571 have weight=0, so the analysis is based on5,306 observations.

HRS-1992-RAND Sample

-Not in the individual Sample SAMPLE SIZE

-At least HH member with missing info SAMPLE SIZE

Couples

Singles
7,337

1,977

5,360

1,443

3,917

2,581

1,336 


\section{Comparison of Rand Data and Sample Characteristics \\ INDIVIDUALS (Weighted Mean values)}

\begin{tabular}{|l|c|c|}
\hline Category & Rand & Paper Sample \\
\hline Number of observations & 13,275 & 7,941 \\
\hline Males: & $47.7 \%$ & $45.9 \%$ \\
\hline Females & $52.3 \%$ & $54.1 \%$ \\
\hline White/Caucasian & $86.2 \%$ & $88.5 \%$ \\
\hline Black/African-American & $10.3 \%$ & $8.8 \%$ \\
\hline Currently Married individuals & $74.4 \%$ & $77.3 \%$ \\
\hline Currently Married or partnered & $76.8 \%$ & $79.5 \%$ \\
\hline Earnings wave 1 & $\$ 22,030$ & $\$ 22,977$ \\
\hline Earnings wave 2 & $\$ 21,218$ & $\$ 22,841$ \\
\hline Earnings wave 3 & $\$ 18,311$ & $\$ 19,896$ \\
\hline Earnings wave 4 & $\$ 16,071$ & $\$ 17,332$ \\
\hline Earnings wave 5 & $\$ 14,053$ & $\$ 14,946$ \\
\hline Earnings wave 6 & $\$ 11,960$ & $\$ 12,542$ \\
\hline Housing wealth wave 1 & $\$ 68,926$ & $\$ 69,281$ \\
\hline Non-housing financial wealth wave1 & $\$ 54,617$ & $\$ 59,618$ \\
\hline
\end{tabular}

HOUSEHOLDS (Weighted Mean Values)

\begin{tabular}{|l|c|c|}
\hline Category & Rand & Paper Sample \\
\hline Number of households & 7,357 & 3,917 \\
\hline Couples & 4,984 & 2,581 \\
\hline Singles & 2,373 & 1,336 \\
\hline Married people as a percent of total & $81 \%$ & $80 \%$ \\
\hline Couples' financial data (wave 1) & & \\
\hline Household earnings & $\$ 42,089$ & $\$ 44,473$ \\
\hline Household wealth & $\$ 154,624$ & $\$ 153,570$ \\
\hline Non-housing financial wealth & $\$ 121,800$ & $\$ 132,960$ \\
\hline Singles' financial data (wave 1) & & \\
\hline Household earnings & $\$ 18,236$ & $\$ 20,384$ \\
\hline Household wealth & $\$ 38,722$ & $\$ 39,756$ \\
\hline Non-housing financial wealth & $\$ 32,103$ & $\$ 36,519$ \\
\hline
\end{tabular}




\section{RECENT WORKING PAPERS FROM THE \\ CENTER FOR RETIREMENT RESEARCH AT Boston COLLEGE}

Bequests, Inheritances and Family Traditions

Donald Cox and Oded Stark, August 2005

Local Labor Market Conditions and Retirement Behavior

Dan A. Black and Xiaoli Liang, May 2005

Validation Study of Earnings Data in the SIPP_Do Older Workers Have Larger Measurement Error?

Peter Gottschalk and Minh Huynh, May 2005

Investment Choice in the Swedish Premium Pension Plan

Mårten Palme, Annika Sundén, and Paul Söderlind, April 2005

Design and Implementation Issues in Swedish Individual Pension Accounts

R. Kent Weaver, April 2005

Lashed to the Mast?: The Politics of Notional Defined Contribution Pension Reforms

Sarah M. Brooks and R. Kent Weaver, January 2005

Understanding Expenditure Patterns in Retirement

Barbara A. Butrica, Joshua H. Goldwyn, and Richard W. Johnson, January 2005

Changes in the Distribution of Long-Run Earnings and Retirement IncomesHave Recent Cohorts Fallen Behind?

Peter Gottschalk and Minh Huynh, January 2005

The Age Profile of Income and the Burden of Unfunded Transfers in Four Countries: Evidence from the Luxembourg Income Study

Gary Burtless, December 2004

Projecting Immigration: A Survey of the Current State of Practice and Theory Neil Howe and Richard Jackson, December 2004

All working papers are available on the Center for Retirement Research website (http://www.bc.edu/crr) and can be requested by e- mail (crr@bc.edu) or phone (617-5521762). 